IZA DP No. 8080

How ICT Investment and Energy Use Influence the Productivity of Korean Industries

Nabaz T. Khayyat

Jongsu Lee

Almas Heshmati

March 2014 


\title{
How ICT Investment and Energy Use Influence the Productivity of Korean Industries
}

\author{
Nabaz T. Khayyat \\ TEMEP, Seoul National University \\ Jongsu Lee \\ TEMEP, Seoul National University \\ Almas Heshmati \\ Sogang University \\ and IZA
}
Discussion Paper No. 8080
March 2014

\author{
IZA \\ P.O. Box 7240 \\ 53072 Bonn \\ Germany \\ Phone: +49-228-3894-0 \\ Fax: +49-228-3894-180 \\ E-mail: iza@iza.org
}

\begin{abstract}
Any opinions expressed here are those of the author(s) and not those of IZA. Research published in this series may include views on policy, but the institute itself takes no institutional policy positions. The IZA research network is committed to the IZA Guiding Principles of Research Integrity.

The Institute for the Study of Labor (IZA) in Bonn is a local and virtual international research center and a place of communication between science, politics and business. IZA is an independent nonprofit organization supported by Deutsche Post Foundation. The center is associated with the University of Bonn and offers a stimulating research environment through its international network, workshops and conferences, data service, project support, research visits and doctoral program. IZA engages in (i) original and internationally competitive research in all fields of labor economics, (ii) development of policy concepts, and (iii) dissemination of research results and concepts to the interested public.
\end{abstract}

IZA Discussion Papers often represent preliminary work and are circulated to encourage discussion. Citation of such a paper should account for its provisional character. A revised version may be available directly from the author. 
IZA Discussion Paper No. 8080

March 2014

\section{ABSTRACT \\ How ICT Investment and Energy Use Influence the Productivity of Korean Industries}

This empirical study examines changes in industrial productivity in Korea between 1980 and 2009, focusing on how investment in information and communication technology (ICT) and energy use, influence productivity levels. A dynamic factor demand model is applied in order to link inter-temporal production decisions by explicitly recognizing that the level of certain factors of production cannot be changed without incurring so-called adjustment costs, defined in terms of forgone output from current production. In particular, we investigate how the ICTenergy relationship affects total factor productivity growth in 30 industrial sectors. Describing industry-specific productivity levels is important for policymakers when the allocation of public investment and support is limited. The results presented herein show that ICT/non-ICT capital investment are substitutes for labor and energy use. We also find a high output growth rate in the sampled sectors, and increasing returns to scale, whose effects on the TFP component are higher than those of technological progress.

JEL Classification: C32, C33, Q41

Keywords: dynamic factor demand, panel data, ICT investment, energy use, productivity

Corresponding author:

Almas Heshmati

Department of Economics

Sogang University

35 Baekbeom-ro (Sinsu-dong \#1)

Mapo-gu, Seoul 121-742

South Korea

E-mail: heshmati@sogang.ac.kr 


\section{Introduction}

Since Schumpeter (1939) emphasized that entrepreneurship is the main engine of economic growth, many researchers have attempted to explain the causal relationship between such growth and technological development. Solow (1957) introduced the residual approach to measure the contribution of technological development to productivity growth. He found that approximately 70 percent of productivity increase is attributed to technological change. Hence, technology is considered to be the main driver of economic growth. Indeed, researchers suggest that ideas and innovations serve to grow total factor productivity (TFP) (Mokyr, 2005), which in turn raises worldwide income per capita, transforms production processes, and modifies the way in which a business runs (Maddison, 2005).

Historical examples of the link between new technologies with growth abound. Since the $18^{\text {th }}$ century when general purpose technologies such as steam engines, electricity, automobiles, and telephones were introduced during the Industrial Revolution, living standards have dramatically increased. Similarly, investment in new information and communication technologies (ICT) in the late 1990s radically changed the underlying structure of advanced economies. For example, after an extended and unexpected stagnation during the 1970s and 1980s, the US experienced high levels of output growth associated with a strong and widespread productivity boom owing to ICT improvements.

Korea is a new industrialized economy that has also taken advantage of technological development, thereby serving as an economic model for emerging economies. It enjoyed a high economic growth rate from the post-war period until 1997, at which point per capita GDP was 10,000 USD. The Korean economy quickly recovered from the Asian financial crisis of the late 1990s, the ICT bubble of 2001, and the credit crunch of 2003 (Borensztein and Lee, 2000; Oh et al., 2012). Moreover, it was the first country to recover within a year from the global economic crisis of 2007/08. In addition, through the conclusion of negotiations on a US-South Korea free trade agreement (FTA) and a potential Japan-South Korea FTA in the future, the liberalization of South Korean markets will continue (Fukao et al., 2009).

The South Korean government applied a sequence of industrial and technological policy initiatives across different stages of its economic development, in which it assisted in interpreting most of the economic variables estimated under this study. A brief description of the history of policy initiative is provided bellow based on literature survey of (Kim, 1997; Oh et al., 2008; Park, 2000):

For the period of the 1980s onward, the policy focused on the growth in foreign direct investment (FDI) concentrating on technology based industries as a source for economic growth. The technology policy was toward encouraging the private sector for innovativeness and R\&D, also called for collaboration between the ministries' R\&D activities. The period of the 1990s saw continuously supported FDI with concentration in technology as a source of economic growth and enhancing the innovation capabilities in the private sector. Therefore, hi-tech sectors were encouraged to internationalize. This period was characterized by highly advanced technology area, ICT, Bio-technology and R\&D collaboration. The globalization era in the 2000s was the last stage of the process of economic growth in South Korea, where the growth was mainly resulting from technology and innovation, and building the national innovation system. 
This study examines the productivity performance of 30 industrial sectors in Korea during the period 1980-2009, and estimates the impacts of factors that affect TFP growth in order to determine whether they have responded to environmental change effectively. In particular, we investigate how the ICT-energy relationship affects TFP growth. Describing industry-specific productivity levels is important for policymakers when the allocation of public investment and support is limited.

The remainder of this paper is organized as follows. Section 2 explains the traditional measure of TFP by using the Divisia Index (DI) approach and describes its limitations. Section 3 presents the theoretical model and derives the factor demand equations for the empirical analysis. In this section, the traditional measure of TFP growth is decomposed based on the effects of technical change, scale, equilibrium, and adjustment costs. It also provides the measures of capacity utilization (CU) within the TFP framework. Section 4 presents the results of the parameter estimates and Section 5 concludes.

\section{The DI Approach}

The DI approach to calculating TFP is based on comparing the growth of output with the growth of inputs. To the extent that over a particular time interval, output grows faster than inputs, there is evidence that productivity has increased (Tangen, 2002). Firms and industries use different inputs such as labor, physical capital, ICT capital, energy use, and materials. Overall input growth is therefore a weighted average of the growth rates of these individual inputs. In the absence of input and output elasticities, the DI method weights inputs and output based on cost and revenue proportions. For example, if twice as much is spent by a firm on labor as on capital, the input index weights the labor input twice as heavily as the capital input. Therefore, as these cost proportions change over time, so too do the weights used in the DI. Similarly, overall output growth can be computed as a weighted average of the growth in the individual outputs. TFP growth over a specific time interval such as a year is then calculated by subtracting the growth of the input index from the growth of the output index.

The accuracy of the DI method rests on four main assumptions that may not hold in practice: (1) technology displays constant returns to scale (RTS), (2) producers operate at the long-run equilibrium, (3) the market is in perfect competition, and (4) input factors are utilized at a constant rate. Owing to these limitations, a parametric flexible framework is developed for computing TFP that relaxes many of the restrictive assumptions inherent in the DI methodology (Nadiri and Prucha, 1986, 1990, 1996, 1999, 2001). The present study applies the Nadiri and Prucha (1990) model in order to provide a rich set of observations on the sampled industrial sectors in Korea. In particular, the analysis presented herein is based on a dynamic factor demand model that links inter-temporal production decisions by explicitly recognizing that certain factors of production cannot be changed without incurring adjustment costs, which are defined in terms of forgone output from current production. While certain (variable) inputs such as labor and materials can be adjusted easily, others such as ICT and non-ICT capital are subject to adjustment costs, and only adjust partially in the first period. These inputs are thus referred to as quasi-fixed, meaning that they are fixed in the short run but variable in the long run.

Further, since output growth is high across industrial sectors in Korea, a priori constant RTS is not imposed; rather, RTS is estimated empirically from the data. Moreover, because the rate of 
ICT capital in the industrial sector is also high, ICT capital is incorporated as one of the inputs herein. In summary, by using structural parameter estimates, this study analyzes the sources of growth in output, TFP, and TFP growth rate.

\section{Theoretical Model and Empirical Specification}

\subsection{The Dynamic Factor Demand}

Consider a firm or industry that employs $m$ variable inputs and $n$ quasi-fixed inputs to produce a single output from a technology with internal adjustment costs. In line with the approach taken by Nadiri and Prucha (1990), the firm's production process can be described by the following generalized production function:

$$
Y_{i t}=F\left(V_{i t}, X_{i t-1}, \Delta X_{i t}, T_{i t}\right)
$$

Where the subscripts $(i=1,2, \ldots)$ and $(t=1,2, \ldots)$ represent industry and time, respectively, $Y_{i t}$ denotes gross output, $V_{i t}$ is a vector of variable inputs, $X_{i t-1}$ is a vector of quasi-fixed inputs, $\Delta X_{i t}$ $=X_{i t}-X_{i t-1}$ is a vector that represents the internalization of the adjustment costs in the production function (in terms of the foregone output) due to changes in the stock of quasi-fixed inputs, and $T_{i t}$ is an exogenous technology index ${ }^{1}$. A change in the levels of the quasi-fixed factors will result in incurring adjustment costs because of the resource allocation require to change the input stock rather than product level.

The duality principle in production theory indicates that given a production function, under the appropriate regularity conditions, it is possible to derive the corresponding firm's total minimum cost function $C(w, Y)$ as the solution to the problem of minimizing the cost of producing a specified level of output as follows:

$$
C(w, Y)=\left\{\min _{x} x w: f(x) \geq Y\right\}
$$

where $x$ is a vector of input quantities and $w$ is a vector of input prices ${ }^{2}$. The production structure can then be described equivalently in terms of a restricted cost function. A perfectly competitive factor input market for the industry should be assumed. The acquisition prices for the variable and quasi-fixed inputs are denoted as $\hat{p}_{\mathrm{i}, \mathrm{t}}^{\mathrm{V}_{\mathrm{s}}}(s=1,2, \ldots, m)$ and $\hat{\mathrm{q}}_{\mathrm{i}, \mathrm{t}}^{\mathrm{X}_{\mathrm{d}}}(d=1,2, \ldots, n)$ respectively. All prices are normalized to the price of the first variable factor - this procedure has been found convenient. These normalized prices are denoted as $\mathrm{p}_{\mathrm{i}, \mathrm{t}}^{\mathrm{v}_{j}}=\hat{\mathrm{p}}_{\mathrm{i}, \mathrm{t}}^{\mathrm{V}_{s}} / \hat{\mathrm{p}}_{\mathrm{i}, \mathrm{t}} \mathrm{V}_{1}$ and $\mathrm{q}_{\mathrm{i}, \mathrm{t}}^{\mathrm{x}_{j}}=\hat{\mathrm{q}}_{\mathrm{i}, \mathrm{t}}^{\mathrm{x}_{\mathrm{t}}} / \hat{\mathrm{p}}_{\mathrm{i}, \mathrm{t}}^{\mathrm{V}_{1}},(\mathrm{j}=$ $1,2, \ldots, \mathrm{m})$. The normalized restricted cost function is then defined as follows:

$$
G\left(p_{i, t}^{V_{j}}, X_{i, t-1}, \Delta X_{i, t}, Y_{i, t}, T_{i, t}\right)=\sum_{j=1}^{m} \hat{p}_{i, t}^{V_{j}} \widehat{V}_{j i, t}
$$

\footnotetext{
${ }^{1}$ The function $F$ is assumed to be twice continuously differentiable, while $\partial F / \partial v>0, \partial F / \partial x_{t-1}>0$, and $\partial F / \partial \Delta X$

$<0$. In addition, $F$ is strictly concave in all arguments, except, possibly, for the technology index.

${ }^{2}$ The cost function $C($.) should validate the regularity conditions: i.e, to be a concave, non-decreasing, and continuous function of $w$, and positive homogeneous of degree one.
} 
where $\widehat{V}_{j i, t}$ denotes the cost-minimizing amounts of variable inputs required to produce the output $Y_{i, t}$ conditional on $X_{i, t-1}$ and $\Delta X_{i, t}$. The normalized restricted cost function $G($.$) assumed$ to be convex in $X_{i, t-1}$ and $\Delta X_{i, t}$, and concave in $\mathrm{p}_{\mathrm{i}, \mathrm{t}}$ and $\mathrm{q}_{\mathrm{i}, \mathrm{t}}$ (Lau, 1986). As mentioned by Jehle and Reny (2001), when the firm is constrained in the short run by a fixed amount of specific inputs for its production, it cannot freely select the optimal amount, meaning that short- and long-run costs differ. Under these assumptions, the firm's cost in period $t$ is specified as follows:

$$
C\left(X_{i, t}, X_{i, t-1}, \Omega_{i, t}\right)=G\left(p_{i, t}^{V}, X_{i, t-1}, \Delta X_{i, t}, Y_{i, t}, T_{i, t}\right)+\sum_{h=1}^{n} q_{i, t}^{X_{j}} I_{h, t}
$$

Where $\Omega_{i, t}$ is a vector composed of $\mathrm{p}_{i, \mathrm{t}}^{\mathrm{v}_{j}}, \mathrm{q}_{\mathrm{i}, \mathrm{t}}^{\mathrm{x}_{j}}, Y_{i, t}$ and $T_{i, t}$. The real investment of the $h^{\text {th }}$ quasifixed input is defined as follows:

$$
I_{h t}=X_{h t}-\left(1-\delta_{h}\right) X_{h t-1}
$$

where $\delta_{h}$ denotes the depreciation rate of the stock of the $h^{\text {th }}$ quasi-fixed input.

The dynamic problem facing the firm is assumed to minimize the expected present value of current and future costs given the initial values of quasi-fixed inputs. The firm's optimization problem can be classified according to the planning horizon into finite and infinite planning horizon. For the infinite planning horizon, the firm's objective function in period $t$ is defined as follows:

$$
\sum_{\mathrm{t}=0}^{\infty} C\left(\mathrm{X}_{\mathrm{t}}, \mathrm{X}_{\mathrm{t}-1, \mathrm{E}} \Omega_{\mathrm{t}}\right)(1+\mathrm{r})^{-\mathrm{t}}
$$

where $E$ denotes the expectations operator conditional on information available at the beginning of period $\tau$ and $r$ is the real interest rate. The firm in each period $\tau$ derives an optimal plan for the quasi-fixed inputs for period $t, t+1, \ldots$, such that equation (6) is minimized subject to the initial stocks $\mathrm{X}_{\mathrm{t}-1 \text {, }}$, and then chooses its quasi-fixed inputs in period $t$ according to this plan. In each period the firm only implement a portion of its optimal input plan. This process is repeated every period in which a new optimal plan is formulated as new information to the exogenous variables are available, and expectations on those variables are modified accordingly. In the case of a finite but shifting planning horizon, where the stock of quasi-fixed inputs at the end of the horizon are assumed to be determined endogenously subject to the assumption of static expectations, the optimal plans converges rapidly to those of the infinite planning horizon model as the planning horizon extends (Nadiri and Prucha, 1990). Accordingly, this study applies the optimal plans for the infinite planning horizon.

The empirical model with the mathematical formulations along with the analysis of the industry's optimization problem is provided in appendix A. The model is specified to employ the optimal levels of the variable inputs materials (M), energy (E), and labor (L) and the quasi-fixed inputs ICT capital (ICT) and non-ICT-capital (K). It is assumed that the variable inputs can be adjusted instantaneously in response to a change in relative input prices. The adjustment of the capital stock in response to changes in relative input prices will be slow.

The demand equations for the quasi-fixed factors are in the form of accelerator model, while the industry's variable inputs are directly derived from the normalized restricted cost function via 
shepherd's lemma. Explicit expressions for the resulting demand equations for the inputs are given in equations (A.8) to (A.12).

\subsection{Effects of TFP Growth}

As discussed in Section 2, the DI is defined as the weighted sum of the growth rate in outputs minus the weighted sum of the growth rate of the input variables, while the weights are the revenue and cost proportions. The Tornqvist index is a discrete approximation to a continuous DI that averages the measures in two adjacent time periods. This index is attractive to scholars because it enables smooth changes and better captures trends. If the TFP growth rate is measured by using the conventional DI, the corresponding Tornqvist index is defined as:

$$
\Delta T F P_{i t}=\Delta \operatorname{lnh}\left(Y_{i t}\right)-\Delta \ln N_{i t}
$$

where $\Delta \operatorname{lnh}\left(Y_{i t}\right)$ is output growth and $\Delta \operatorname{lnN}_{i t}$ is the growth rate of the cost-weighted index of aggregate inputs. The input growth rate is then defined as:

$$
\Delta \ln N_{i t}=\frac{1}{2}\left\{\left[\sum_{j}\left(\frac{p_{i, t}^{V^{j}} V_{i, t}^{j}}{C_{i, t}}+\frac{p_{i, t-1}^{V^{j}} V_{i, t-1}^{j}}{C_{i, t-1}}\right) \Delta \ln V_{i, t}^{j}\right]+\left[\sum_{j}\left(\frac{q_{i, t}^{X^{j}} X_{i, t-1}^{j}}{C_{i, t}}+\frac{q_{i, t-1}^{X^{j}} X_{i, t-2}^{j}}{C_{i, t-1}}\right) \Delta \ln X_{i, t-1}^{j}\right]\right\}
$$

where $C_{i t}=M_{i, t}+p_{i, t}^{L} L_{i, t}+p_{i, t}^{E} E_{i, t}+q_{i, t}^{K} K_{i, t-1}+q_{i, t}^{I C T} I C T_{i, t-1}$ is total cost $C$, the variable inputs are represented by the vector $V^{j}$ and the quasi-fixed inputs by the vector $X^{j}$, while $p_{i, t}^{V}$ and $q_{i, t}^{X}$ are price of the variable inputs and the long-run rental prices for quasi-fixed inputs, respectively.

The technical change measure of Solow (1957) is often calculated as the difference between the growth rates of aggregated output and the growth rate of aggregated weighted inputs. However, as argued by Nadiri and Prucha (2001), TFP growth based on the DI will generate biased estimates of technical change, which may include scale effects and temporarily equilibrium effects, if any one of the sets of the assumptions of the DI has been biased and violated. The empirical results and unrealistic restrictiveness of these assumptions have led researchers to prefer alternative parametric TFP growth measures. Accordingly, TFP growth in this study is decomposed as follows (Nadiri and Prucha, 1986, 1990, 2001):

$$
\Delta T F P_{i, t}=\Delta T F P_{i, t}^{T}+\Delta T F P_{i, t}^{S}+\Delta T F P_{i, t}^{E}+\Delta T F P_{i, t}^{A}
$$

Thus, the overall TFP growth rate is decomposed into the effects of the following factors: technical change, scale, equilibrium, and direct adjustment costs.

Based on the Tornqvist notion, the effect of technical change is described as follows:

$$
\Delta T F P_{i, t}^{T}=\frac{1}{2}\left[\lambda_{x}(t)+\lambda_{x}(t-1)\right]
$$

where the input-based measure of technical change is obtained from: 


$$
\lambda_{x}=-\frac{\partial G_{i, t}}{\partial T_{i, t}} /\left[G_{i, t}-\left[\sum_{j} \frac{\partial G_{i, t}}{\partial X_{i, t-1}^{j}} X_{i, t-1}^{j}+\sum_{j} \frac{\partial G_{i, t}}{\partial \Delta X_{i, t}^{j}} \Delta X_{i, t}^{j}\right]\right]
$$

This measure of technical change corresponds to the decrease in input use achieved through technical change without decreasing output (Caves et al., 1982; Caves et al., 1981).

The output based measure of technical change is obtained from:

$$
\lambda_{Y}=-\frac{\partial G_{i t}}{\partial T_{i, t}} /\left(\frac{\partial G_{i, t}}{\partial Y_{i, t}} h\left(Y_{i, t}\right)\right)
$$

The return to sale is defined as $\varepsilon=\frac{\lambda_{Y}}{\lambda_{x}}$ and the technical change $T C=(\partial G / \partial t) / C$ (Nadiri and Prucha, 1990). The output-based measure of technical change is the rate of expansion in output achieved by technical change without changing the input use (Caves et al., 1982; Caves et al., 1981).

The scale effect, or deviation from constant RTS, is specified as follows:

$$
\Delta T F P_{i, t}^{S}=\left(1-\varepsilon_{i . t}^{-1}\right) \Delta \ln \left(h\left(Y_{i, t}\right)\right)
$$

The temporary equilibrium effect is specified as follows:

$$
\Delta T F P_{i, t}^{E}=-\frac{1}{2} \sum_{\tau=t, t-1}\left\{\sum_{j} \frac{\left(\partial G_{i, \tau} / \partial X_{i, \tau}^{j}+q_{i, \tau}^{X^{j}}\right) X_{i, \tau}^{j}}{\varepsilon_{i, \tau}\left(\partial G_{i, \tau} / \partial h\left(Y_{i, \tau}\right)\right) h\left(Y_{i, \tau}\right)}\left[\Delta \ln X_{i, \tau}^{j}-\Delta \ln N_{i, t}^{\tau}\right]\right\}
$$

Finally, the direct adjustment cost effect is described as follows:

$$
\Delta T F P_{i, t}^{A}=-\frac{1}{2} \sum_{\tau=t, t-1}\left\{\sum_{j} \frac{\left(\partial G_{i, \tau} / \partial \Delta X_{i, \tau}^{j}\right) \Delta X_{i, \tau}^{j}}{\varepsilon_{i, \tau}\left(\partial G_{i, \tau} / \partial h\left(Y_{i, \tau}\right)\right) h\left(Y_{i, \tau}\right)}\left[\Delta \ln \Delta X_{i, \tau}^{j}-\Delta \ln N_{i, t}^{\tau}\right]\right\}
$$

The detailed decomposition of the TFP is provided in Appendix B based on the Lemma developed by Nadiri and Prucha (1990).

\subsection{Measure of CU}

The marginal value products of the quasi-fixed factors represented by shadow prices differ from their rental prices because of the presence of adjustment costs. Such differences ensure the existence of market disequilibrium effects. If the adjustment to the long-run equilibrium is instantaneous, the rental prices would be equal to the shadow prices, and the effect of the temporary equilibrium on the change in TFP would be zero. However, if the shadow prices are greater than the rental prices, the existing stocks of the quasi-fixed inputs are over-utilized, which implies that CU is greater than one. Any attempt to reach full CU raises TFP, with higher 
investment rates positively related to TFP and vice versa. How the direct adjustment cost affects the TFP change is thus uncertain ${ }^{3}$.

The temporary short-run equilibrium may occur in two ways: (i) when unexpected demand shocks lead to capacity under/over-utilization or (ii) when sudden changes in factor prices result in increase/decrease in short-run relative factor usage, which is unsuitable in the long run (Berndt and Fuss, 1986). One of the most common examples of the temporary equilibrium is the existence of excess capacity, say because of a reduction in output demand. Accordingly, it is necessary to measure CU as well as TFP in the presence of variation in the former.

Following Nadiri and Prucha (1996), the CU measure can be defined based on the ratio of shadow cost to total cost. This measure is called the shadow valuation measure of CU. The total cost normalized by the price of materials input is defined as follows:

$C_{i, t}=M_{i, t}+\mathrm{p}_{i, t}^{L} L_{i, t}+\mathrm{p}_{i, t}^{E} E_{i, t}+\mathrm{c}_{i, t}^{K} K_{i, t-1}+\mathrm{c}_{i, t}^{I C T} I C T_{i, t-1}=$
$G\left(\mathrm{p}_{i, t}^{L}, \mathrm{p}_{i, t}^{E}, \mathrm{q}_{i, t}^{K}, \mathrm{q}_{i, t}^{I C T}, h\left(Y_{i, t}\right), K_{i, t-1}, I C T_{i, t-1}, \Delta K_{i, t}, \Delta I C T_{i, t}, T_{i, t}\right)+\left(1+r_{i, t}\right) \mathrm{q}_{i, t}^{K} K_{i, t-1}+$
$\mathrm{c}_{i, t}^{I C T} I C T_{i, t-1}$

where $G($.$) is the normalized restricted variable cost function defined in equation (3), while$ $c_{i, t}^{I C T}=\mathrm{q}_{i, t}^{I C T}\left(r_{i, t}+\delta_{i, t}^{I C T}\right)$ and $\mathrm{c}_{i, t}^{K}=\mathrm{q}_{i, t}^{K}\left(r_{i, t}+\delta_{i, t}^{K}\right)$ are the rental prices of ICT and non-ICT capital, respectively. Shadow cost $C^{s}$ is shown in equation (B.2) in appendix B. The CU measure can then be defined as the ratio of shadow cost to total cost:

$$
\mathrm{CU}=\mathrm{C}^{\mathrm{s}} / \mathrm{C}
$$

The CU measure above implies a deviation from unity because of the quasi-fixed effect of capital on the short-run temporary equilibrium.

\section{Estimation and Empirical Results}

\subsection{Data and Estimation Procedures}

In this study, the production structure and factor demand outlined above are estimated for a panel dataset of 30 industrial sectors in Korea for 1980-2009. We also analyze the data by three subsample periods, namely 1980-1989, 1990-1999, and 2000-2009 ${ }^{4}$. A detailed description of the data used in this study and the constructed variables are reported in Table C.1 in Appendix C. Details of the industries and their characteristics are described in Table C.2. The estimation results reported in Table C.3 are based on an infinite planning horizon and static expectations for output and factor prices. The system equations include dummy variables in order to capture

\footnotetext{
${ }^{3}$ It should be noted that when a firm invests in capital, they may need to divert resources toward installing new capital rather than producing marketable output, which means that in periods of rapid investment growth, firms could be producing two types of products: the final product sold in the market and the services used within the firm to install capital. Marketable output may therefore be lower in periods of high investment growth, and this would cause a downward bias in the estimates of measured productivity growth.

${ }^{4}$ The aim is to reflect the possible structural changes in the Korean economy due to the implementation of economic development plans as described in section 1.
} 
industry-specific effects because the presence of heterogeneity across sectors cannot be explained by the production structure alone ${ }^{5}$. The Durbin-Watson and White tests show serial correlation and heteroskedasticity in the residuals. The variance-covariance estimator used for the FIML method is from the generalized least squares estimator. Therefore, the generalized least squares approximation to the Hessian is used in the minimization procedure based on the recommendation in Nadiri and Prucha (1990).

The parameter estimates satisfy the conditions of the convexity of the normalized restricted cost function in ICT and non-ICT capital, and the concavity in variable input prices. Further, the parameter estimates $a_{K K}, a_{\dot{K} \dot{K}}, a_{I C T I C T}$, and $a_{I \dot{C} T I \dot{C} T}$ are positive, while $a_{l l}$ and $a_{e e}$ are negative. The hypothesis of the absence of adjustment costs for the quasi-fixed inputs $K$ and ICT, $a_{\dot{K} \dot{K}}=0$ and $a_{I \dot{C} T I \dot{C} T}=0$ is thus rejected. Hence, we deem the static equilibrium model to be unsuitable for describing the technology and structure of the factor demand of Korean industries.

The demand for variable inputs depends negatively on their own normalized prices. The negative signs of the quasi-fixed inputs of ICT and non-ICT capital in the labor and energy demand functions indicate that ICT and non-ICT capital are substitutes for labor and energy use. Significant coefficients for the industry dummy variables imply significant differences in the cost structure across industries. RTS can be calculated based on the estimated parameters $\Omega_{0}$ and $\Omega_{1}$. The parameter estimates per se are difficult to interpret. Consequently in the following, estimates for various implied characteristics for the estimated factor demand systems are presented.

\subsection{Adjustment Costs}

The optimal paths for the quasi-fixed inputs of ICT and non-ICT capital are described by the flexible accelerator coefficients in equations (A.7.3) and (A.7.4). In each period, a proportion of the difference between the initial stocks of these two quasi-fixed capitals and the respective longrun optimal values adjusted is similar. The partial adjustment is caused by the cost of investment in capital. However, the long-run optimal values change over time in response both to changes in those variables exogenous to the firm's input decisions, and to changing market conditions. These coefficients are essential for determining the investment patterns of the quasi-fixed factors. Omitting these terms would lead to misspecification of investment patterns and inconsistency in the estimates of the other technology parameters (Nadiri and Prucha, 1990).

The estimated adjustment coefficients for ICT and non-ICT capital, $m_{k k}$ and $m_{\text {ICTICT }}$ are reported in Table 1. Note that when the value of the adjustment coefficient is close to zero (unity), it implies that the stock of the quasi-fixed input moves slowly (quickly) toward the optimal value.

Table 1

The Coefficients of the Adjustment Speed

\begin{tabular}{ccc}
\hline & $\mathrm{m}_{\mathrm{kk}}$ & $\mathrm{m}_{\text {Iстіст }}$ \\
\hline Mean & 0.181 & 0.244 \\
\hline Std Dev & 0.007 & 0.0071 \\
\hline
\end{tabular}

\footnotetext{
${ }^{5}$ Fixed effect approach is applied for panel data. The coefficients of dummy variable are not reported to save space.
} 


\begin{tabular}{lll}
\hline Minimum & 0.167 & 0.231 \\
\hline Maximum & 0.193 & 0.256 \\
\hline
\end{tabular}

We see that ICT capital adjusts faster than non-ICT capital. It closes approximately one-quarter of the gap between the initial and desired stock in the first period, while non-ICT capital only closes approximately one-fifth of this gap. The fast adjustment of ICT capital concurs with the findings of Kim and Park (2009), who argued that technological flows across industries that use ICT have positive relationships with time. In addition, the fast trend in the speed of ICT adjustment is due to technological diffusion, which has been shown to strengthen technology linkages across industries since the 1990s. Moreover, high investment in ICT is partly due to the rapid decline in ICT capital prices, which allowed for substituting between different types of capital goods. Investment in ICT capital might be driven by the perceived benefits that industries expect from ICT such as higher efficiency (López-Pueyo and Mancebón, 2010; Pilat and Lee, 2001).

To indicate the disequilibrium in the factor inputs from a long-run point of view, the percentage difference of the actual values from the long-run optimal values for the respective inputs are presented in Table 2. The long-run optimal values for ICT capital ICT* and non-ICT capital $K^{*}$ are defined in equations (A.7.5) and (A.7.6), respectively, while those for the variable inputs (i.e., labor, energy use, and materials) are obtained by substituting $I C T^{*}$ and $K^{*}$ into equations (A.10), (A.11), and (A.12), respectively. The percentage deviations are calculated as $\left(100 * \frac{X_{i, t}-x_{i, t}^{*}}{x_{i, t}^{*}}\right)$ where $X_{i, t}$ and $X_{i, t}^{*}$ represent the estimated and optimal inputs factors, respectively.

Table 2

Average Percentage Deviation of Actual Value from the long run optimal values by Sub-period

\begin{tabular}{llllll}
\hline Years & Capital & ICT & Labor & Materials & Energy \\
\hline $1981-1989$ & 0.060 & -0.465 & -0.360 & -0.190 & -0.085 \\
\hline $1990-1999$ & 0.007 & -0.533 & 0.964 & -0.048 & -0.023 \\
\hline $2000-2009$ & 0.051 & -0.039 & 1.971 & 0.087 & 0.112 \\
\hline
\end{tabular}

Non-ICT capital exceeds the long-run optimal value, whereas the reverse is true for ICT capital. At the beginning of the sample period, labor was less than optimal but then it dramatically increased to exceed the optimal value. Energy was overused during the third sub-period. Further, the gap between actual energy use and the long-run optimal value widened during this sub-period, indicating more energy use in the sampled Korean industries during the 2000s. By contrast, there was a substantial decline in the gap in ICT capital during the third sub-period. The negative values indicate that investment in ICT capital in Korean industries is suboptimal. Moreover, there is also the opportunity to invest more in ICT in order to bridge the gap between its actual and long-run optimal values.

\subsection{RTS}

For all the sampled industrial sectors, we find significant scale effects (average RTS $=1.5$ ), suggesting substantial differences in productivity growth. Our finding that the production 
structures of the sampled sectors are characterized by increasing RTS is in line with those of some previous studies. For example, Kwack and Sun (2005) and Park and Kwon (1995) found similar results with regard to the existence of scale economies and increasing RTS in Korea. On the contrary, Kim and Han (2001) and Oh et al. (2008), although based on different datasets and periods, found constant and even decreasing RTS in Korean manufacturing industries. Table 3 highlights the slight decreasing trend in RTS over time (see also Figure 1), implying that Korean firms are moving toward an efficient size and technical optimal scale by downsizing (Oh et al., 2012).

Table 3

RTS and Technical Change by Sub-period

\begin{tabular}{lll}
\hline Years & TC & RTS \\
\hline $1981-1989$ & 0.69 & 1.52 \\
\hline $1990-1999$ & 0.38 & 1.51 \\
\hline $2000-2009$ & 1.10 & 1.49 \\
\hline Whole Sample & 0.72 & 1.50 \\
\hline
\end{tabular}

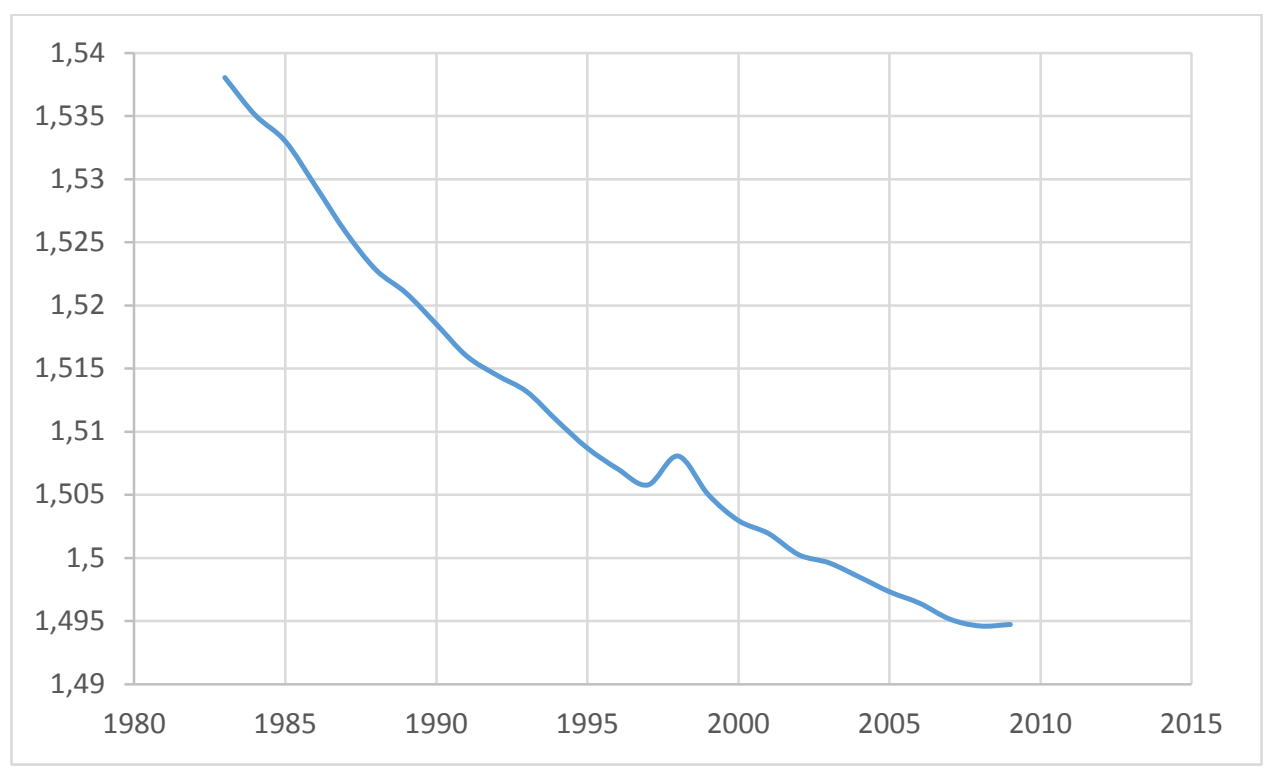

Figure 1: RTS by Year

The average RTS by industry are plotted in Figure 2. It shows that the electrical \& optical equipment, post \& telecommunications, and transport equipment sectors (i.e., high-tech and export-based industries) have the highest RTS values. According to Edwards (1992), many empirical studies have shown that trade liberalization has played a significant role in the rapid growth of East Asian countries, especially South Korea. Subsequently, two streams of the literature have sought explain the link between trade liberalization and economic growth. The first group is the trade literature, which bases this relation on economies of scale (Ethier, 1982; Krugman, 1994) and the advantageous competitiveness environment for trade (Krueger and 
Tuncer (1982). The theoretical models related to the former, for instance, emphasize that trade allows for the further utilization of scale economies that are limited by the size of the domestic market. The second research strand is related to endogenous growth theory, which suggests that economies of scale, human capital accumulation, and technological progress are all forces that make trade liberalization a driver of economic growth (Hwang, 2003).

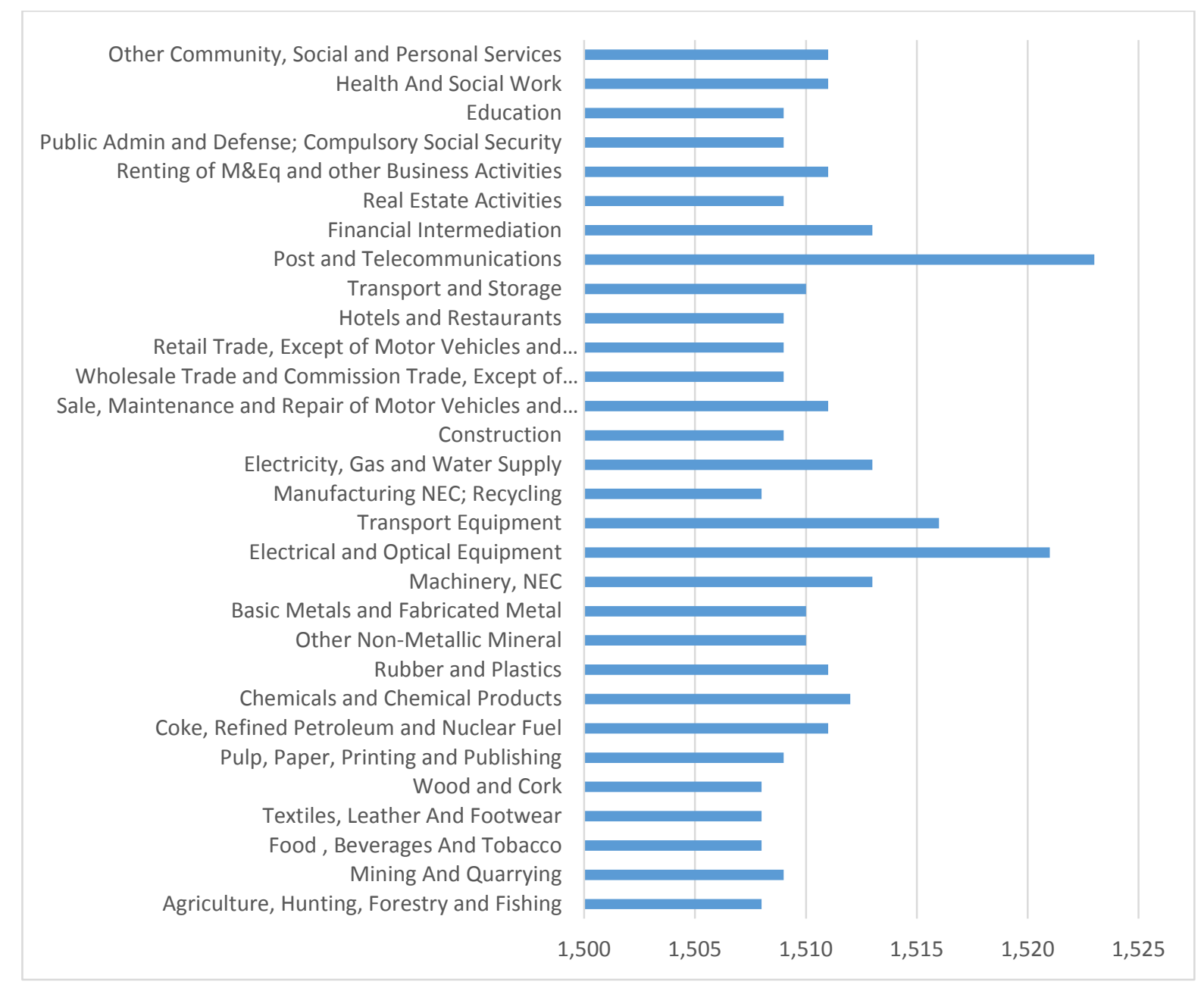

Figure 2: RTS by Industry

\subsection{Technical Change}

According to the technical change measure, the average rate is estimated to be -0.69 percent, suggesting that technological progress has led, on average, to approximately 0.7 percent reduction in total cost per year (decreasing from -0.7 percent in 1980-1989 to -1.0 percent in 2000-2009). Similarly, Kwack and Sun (2005) estimated the average reduction of technical change to be 2 percent of total cost for 1969-2000, implying the existence of Schumpeterian as well as neutral technical change. The pure technical change represented by a simple time trend in our model suggests a reduction of 0.2 percent of total cost $\left(a_{t}=-0.002\right)$. The overall mean rate of technical change also decreases during the study period (see Table 1); however, no uniform 
pattern can be detected. The rate of technical change rapidly increased in 1990-1999 in the aftermath of the Asian financial crisis but dropped again between 2000 and 2009.

The extent of technology change varies by industry ${ }^{6}$. For example, of the 10 industries that have the highest rate of technical change (see Figure 3), only two are classified as low-tech, only three are domestic market-oriented, and only one has low R\&D expenditure. This finding implies that high-tech industries, export-based industries, and industries that show higher R\&D are technically more efficient in general. In other words, technological growth usually comes from R\&D expenditure.

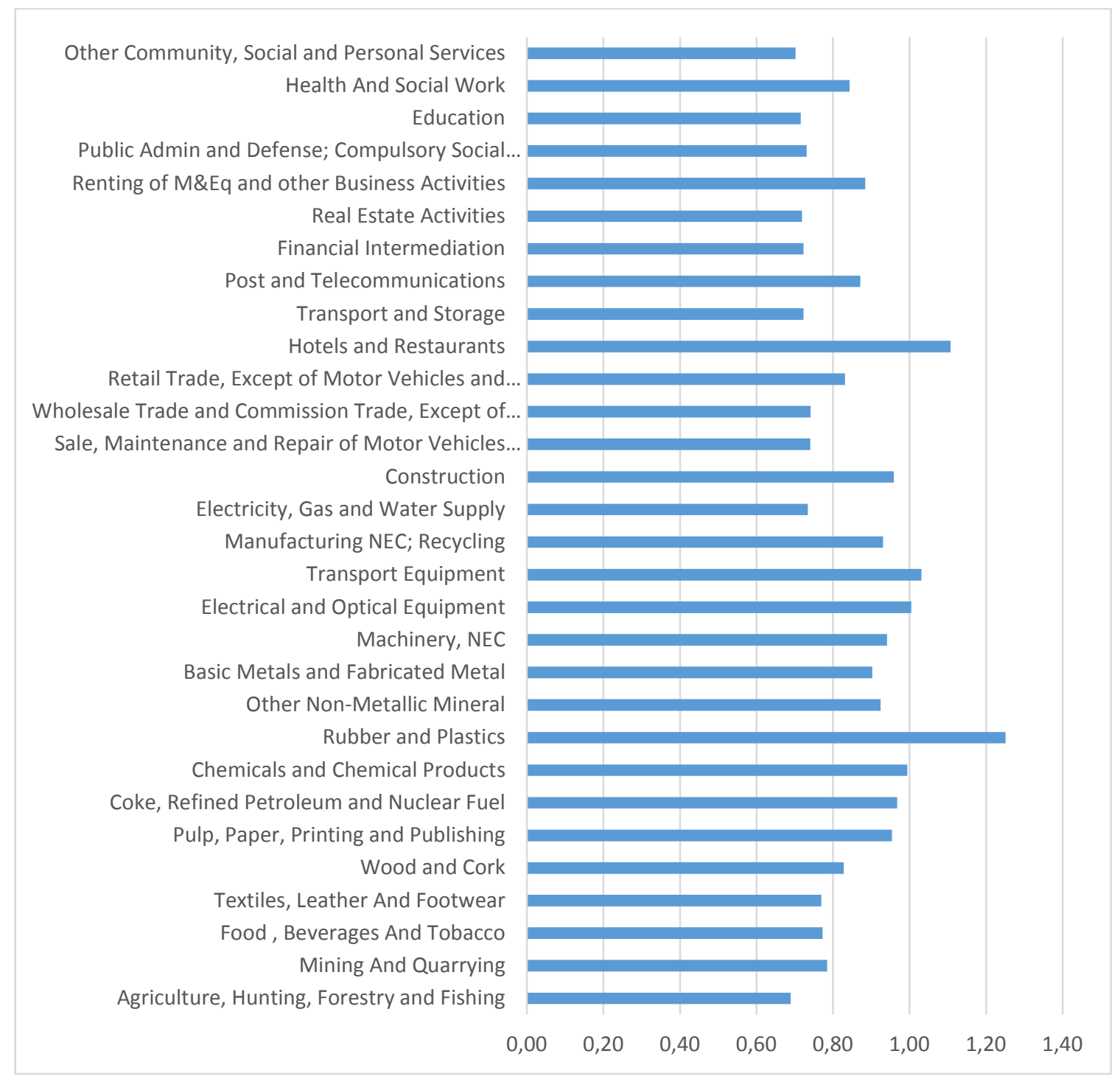

Figure 3: Average Rate of Technical Change by Industry

\footnotetext{
${ }^{6}$ The technical change is negative on the cost function. We changed the sign to positive for illustration.
} 


\subsection{Price and Output Elasticity}

The own- and cross-price elasticities of the inputs for 1995 for the sampled industrial sectors are reported in Table C.4 in Appendix C. These elasticities are calculated for the short- and long-run for each input. All the own-price elasticities have the expected negative sign. The own-price elasticity of ICT capital is largest among all inputs, followed by non-ICT capital, labor, energy use, and materials. However, although the cross-price elasticities are smaller compared with the own-price elasticities, some are nevertheless sizable (e.g., the elasticities of ICT capital with respect to the wage rate, energy price, and materials price). Furthermore, the own-price elasticities of all inputs except for ICT capital are inelastic (less than unity). There are also differences between the short- and long-run own-price elasticities of all the variable inputs, suggesting slow adjustment to long-run steady-state levels.

Because ICT and non-ICT capital are treated as quasi-fixed factors, there is no adjustment in the short run (i.e., their short-run elasticities are zero). In the long run, the own-price elasticity of non-ICT capital (ICT capital) demand is inelastic (elastic); therefore, ICT capital has a substitution relationship with energy use and labor. These results agree with the finding of Park and Park (2003), who argued that Korean industries increasingly deploy ICT in order to reduce the use of labor, and thus that skills-biased technological change is emerging. In other words, the use of ICT, although replacing low-skilled labor, is creating high-skilled complex jobs. Many studies in the fields of manufacturing and technical processes have also indicated that investing more in ICT capital substantially reduces energy use (Cho et al., 2007; Erdmann and Hilty, 2010; Røpke and Christensen, 2012). Finally, the elasticity of ICT with respect to energy use is larger than that of energy use with respect to wage rate, implying that ICT has stronger substitutability with energy use.

The long-run elasticities of the inputs exceed their short-run values and thus they reflect sizable economies of scale. The patterns of the output elasticities indicate that labor and materials respond strongly to short-run changes in output, because labor, energy use, and materials overshoot their long-run equilibrium values in the short run in order to compensate for the sluggish adjustment of the quasi-fixed factors. In brief, they slowly adjust toward their long-run equilibrium values as ICT and non-ICT capital adjusts. Indeed, the positive output elasticity of energy use suggests that economic growth leads to higher energy use. Therefore, although economic growth may improve productivity per unit of energy use, it increases total energy use and $\mathrm{CO} 2$ emissions.

\subsection{TFP Growth}

Based on equations (9)-(15), the growth rate of TFP ( $\triangle \mathrm{TFP}$ ) is divided into the three sub-periods (see Table 4). The results indicate that the scale effect is by far the most important contributor to TFP growth. During the 1980s, the Korean government directed the country's limited national resources toward promoting the heavy and chemicals manufacturing sectors. One of the policy objectives was to enable firms to grow large enough to utilize scale economies and compete in foreign markets (Kim and Han, 2001). While many studies have showed technological progress to be a key contributor to TFP growth (see the literature survey by Kim and Han, 2001), we found a small technical change factor (less than 1.0 percent). Similarly, the effects of adjustment 
costs and the temporary equilibrium are also negligible, implying a slightly inefficient allocation of production inputs with a resulting decline in TFP.

Table 4

Decomposition of Traditional Measure of Average TFP Growth (in percentage)

\begin{tabular}{lcccccl}
\hline Years & $\begin{array}{c}\text { TFPT } \\
\Delta\end{array}$ & $\begin{array}{c}\text { TFPS } \\
\Delta\end{array}$ & $\begin{array}{c}\text { TFPE } \\
\Delta\end{array}$ & $\begin{array}{c}\text { TFPA } \\
\Delta\end{array}$ & $\begin{array}{l}\text { TFP } \\
\text { (Divisia }^{7} \text { ) }\end{array}$ & $\begin{array}{l}\text { Unexplained } \\
\text { estimation } \\
\text { residual }\end{array}$ \\
\hline $1981-1989$ & 0.67 & 2.20 & -0.010 & -0.001 & 6.00 & 3.12 \\
\hline $1990-1999$ & 0.83 & 2.32 & 0.010 & -0.080 & 6.29 & 3.21 \\
\hline $2000-2009$ & 0.99 & 2.92 & 0.003 & -0.026 & 8.35 & 4.47 \\
\hline
\end{tabular}

The contributions of the inputs, technical change, and adjustment costs to output growth are reported in Table 5 (the decomposition is based on the approximation in equation (B.2) in Appendix B). We find that the average growth rate of output is approximately 7.3 percent per year over the entire sample period, whereas the effect of technical change on output is only 0.7 percent on average. Moreover, the various inputs influence output growth to different degrees. The highest rate of contribution is that of energy use followed by labor and materials. Further, non-ICT capital has a greater effect than ICT capital, which, given the proportion of ICT capital in total capital, is reasonable. These results are also consistent with the similar study carried out by Pyo et al. (2007), who reported an average output growth rate of 9 percent.

Table 5

Decomposition of Output Growth (Average annual rate of growth in percentage)

\begin{tabular}{llllllllll}
\hline & \multirow{2}{*}{$\begin{array}{l}\text { Output } \\
\text { Years }\end{array}$} & Labor & Material & Energy & Capital & ICT & \multicolumn{2}{c}{ Adjustment Cost } \\
\cline { 6 - 8 } & & Effect & Effect & Effect & Effect & Effect & Capital & ICT & TC \\
\hline $1981-1989$ & 6.35 & 0.51 & 2.58 & 2.69 & 0.05 & 0.05 & -0.04 & -0.02 & 0.69 \\
\hline $1990-1999$ & 6.86 & 0.67 & 0.75 & 3.03 & 2.4 & 0.03 & -0.13 & -0.16 & 0.38 \\
\hline $2000-2009$ & 8.78 & 0.85 & 3.47 & 3.07 & 0.05 & 0.18 & -0.19 & -0.11 & 1.00 \\
\hline
\end{tabular}

\subsection{CU Index}

The CU index for the three sub-periods is reported in Table 6. The results of this measure indicate optimistic investment for the final two sub-periods (the excess of unity indicates capacity over-utilization; (See Berndt and Morrison, 1981; Morrison, 1986 for details about CU measures). Moreover, the CU increases by approximately 8 and 13 percent for the 1990-1999 and 2000-2009 sub-periods, respectively, reflect the corresponding increase in output.

\footnotetext{
${ }^{7}$ The divisia measure is explicitly taken from the dataset for the sake of comparison with the estimated components.
} 
Table 6

Measure of CU for the Korean Industrial Sectors

\begin{tabular}{ll}
\hline Year & CU index \\
\hline $1980-1989$ & 0.965 \\
\hline $1990-1999$ & 1.045 \\
\hline $2000-2009$ & 1.196 \\
\hline
\end{tabular}

The CU measure including non-static expectations tends to be less than unity whenever an industry is investing extra in anticipation of, for example, output increases that are not justified by the current economic conditions. This result indicates that production sits to the right of the minimum point of the short-run average total cost curve, thereby inducing cost-reducing net investment for the final two sub-periods and cost-increasing net investment during 1980-1989. Nevertheless, the CU rate is increasing over time for the whole sample period (see Figure 4).

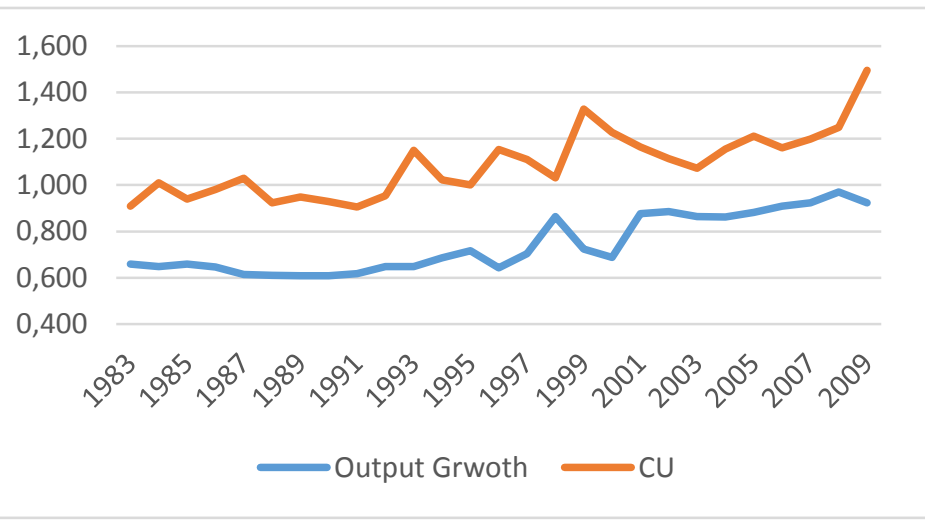

Figure 4: CU Measure Trend and Output Growth over Time

\section{Discussion and Conclusion}

This study modeled the production structure and behavior of the factor inputs that affect production. In addition, it derived the sources of TFP growth by using a dynamic factor demand model for 30 Korean industrial sectors during the period 1980-2009. The sampled industries have experienced a high rate of output growth and demonstrated weak technological progress, as measured by the exogenous time trend that represents technical change or a shift in production/cost functions over time. The model used herein also allowed for scale effects and for quasi-fixed of two input factors, namely ICT and non-ICT capital. By including ICT capital, the model was thus able to capture the technological characteristics of the sample industries.

The main results of this study can be summarized into the following six points. First, the production structures of the sampled sectors are characterized by increasing RTS. The responses of the factors of production to a change in factor price and output in both the short- and the longrun are similar. Likewise, in both the short-and the long-run, ICT has a substitution relationship with energy use, substitutes labor, but complements materials. Further, energy use has a 
substitution relation with materials and labor, whereas labor complements both ICT and non-ICT capital.

Second, the stock of ICT capital adjusts faster than that of non-ICT capital, implying that Korean industries are capital-intensive; hence, relaxing the assumption of constant RTS in our methodology was appropriate. The ratio of actual to optimal energy use was negative for the first two sub-periods of the dataset but overused in the third sub-period. According to Table 7, which provides an energy intensity indicator, there was a steady decline in the energy intensity of Korean industries of an average rate of 85 percent from the first sub-period to the second, but energy intensity slightly increased in the third sub-period. However, despite this decline in energy intensity, this measure is expected to remain above those of all other IEA countries (IEA, 2012).

Table 7

Growth in value added and change in energy intensity at the aggregate economy level

\begin{tabular}{lrrr}
\hline & \multicolumn{3}{c}{ Average Annual Growth rate } \\
\hline & $1981-1989$ & $1990-1999$ & $2000-2009$ \\
\hline Energy Intensity & 1.74 & 0.94 & 0.99 \\
\hline Value Added & 2.73 & 1.95 & 0.74 \\
\hline
\end{tabular}

In addition, Korea's target of a 30 percent emissions reduction by 2030 has led the government to pursue a series of aggressive energy efficiency policies (IEA, 2012). Indeed, the Korean government is continually transforming its economy from one based on large heavy industry that is energy-intensive and low value added to one based on high-tech industries that consume less energy and are high value added (Eichengreen et al., 2012). However, while the energy trends for the first two sub-periods concur with this shift in industrial focus, energy use increased by 11 percent from the optimal level in the third sub-period (see Table 2 and Figure 5). Thus, the substitution relation between ICT capital and energy use (as found in this study) may help overcome this issue. In short, there is room for more investment in ICT in order to lower energy intensity in Korea's industrial sectors consistent with its environmental goals.

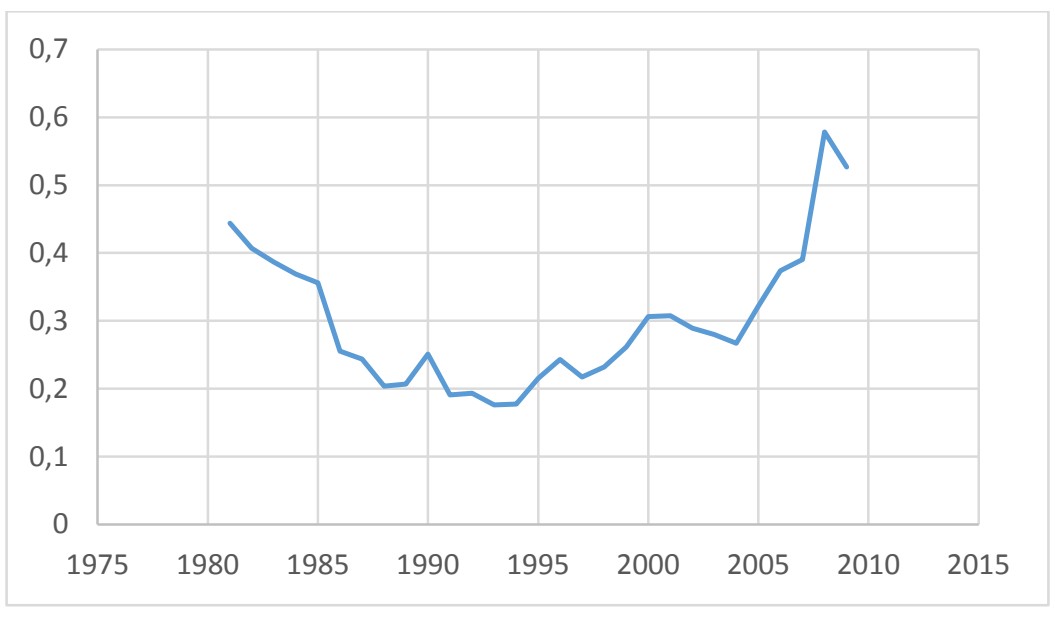

Figure 5: Average Industry Energy Intensity by Year 
Third, TFP growth in Korean industry is positively affected by economies of scale above all other influencing factors. By contrast, technical change has a small positive effect on TFP growth. A possible explanation for this finding is that Korean industries have reached a level of technological sophistication from where it is difficult to make substantial additional progress; hence, they settle for taking advantage of the available scale effects.

Since the 1980s, policymakers have focused on growing foreign direct investment by concentrating on technology-based industries. Such a technology-led policy has encouraged the private sector to invest in innovativeness and R\&D as well as called for collaboration between ministries' R\&D activities (Park, 2000). In the 1990s, the Korean government continuously supported foreign direct investment in technology sectors and enhanced innovation capabilities in the private sector. The globalization era in the 2000s was then the last stage of the process of economic growth in Korea, where growth was mainly driven by technological progress and innovation. During that period, R\&D investment sharply increased (Park, 2000) and high-tech sectors were encouraged to internationalize their technological development needs. Many scholars have emphasized the relationship between R\&D expenditure and ICT investment and the role of both drivers in productivity growth (See for example: Hall et al., 2012; Polder et al., 2009; van Ark et al., 2003). Figure 6 illustrates the high correlation between R\&D expenditure and ICT capital (0.949 and 0.951 for one and two lags, respectively), which indicates that more investment in ICT results from greater R\&D spending.

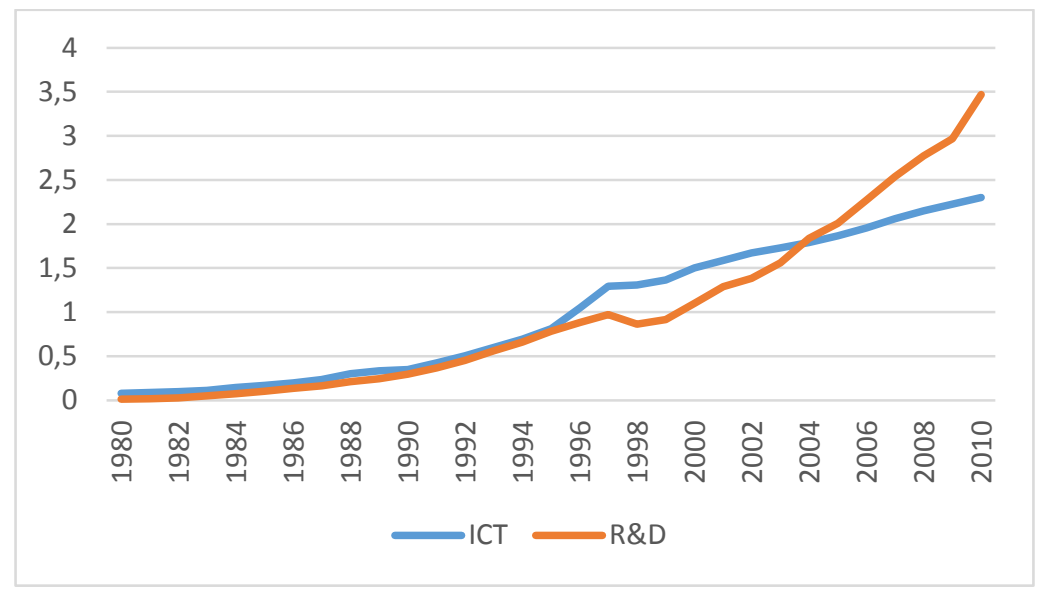

Figure 6: Correlation between ICT capital and $R \& D$ investment

Fourth, the temporary equilibrium effect is another source of TFP growth. A positive temporary equilibrium effect indicates that, on average, the rental prices of quasi-fixed inputs are less than the shadow prices, implying that quasi-fixed inputs are over-utilized. Increasing investment in ICT capital can therefore enhance the competitiveness of Korean industries at the global level and hence their productivity. The scale effects experienced by Korean industries suggest that their growth strategy should no longer focus on expansion in terms of firm size. An individual industry may still improve efficiency by catching up to the best practice frontier of the industry globally. When this possibility is exhausted, however, TFP change may stop.

Fifth, the unexplained residual source of TFP (average 3.6 percent) may come from the assumption of perfect goods and factor markets and possible errors in the measurement of inputs. Kwack and Sun (2005) and Berthélemy and Chauvin (2000) found that the unexplained residuals 
of TFP account for 1.3 percent and 1.2 percent, respectively. Further, Huggett and Ospina (2001) showed that the purchases of new technology equipment initially reduce TFP growth. The unexplained residuals may then be attributed to the under-utilization of certain imported capital goods, especially high-tech equipment, owing to their technological sophistication being beyond Korean technological capability in short run. Further, overinvestment and idle imported capital equipment raise the cost of capital as well as their contribution to output, diminishing productivity and negatively affecting TFP growth (Kwack and Sun, 2005). Hence, in order to analyze the unexplained proportion of TFP, new models that incorporate other factors explaining the decomposition of TFP should be developed.

Sixth, Korea's successful export-oriented industrial policy suggests that sector-level energy efficiency is high compared with other developed countries (IEA, 2012). However, there is room for further improvement, such as greater clarity on sector-specific targets, clear complementary plans and time schedules, and greater coordination and cooperation among government ministries and agencies. As recommended by IEA (2012), Korea may also be capable of strengthening its efforts to improve data collection and analysis for monitoring and evaluating the results of the impact of energy efficiency policies across all sectors of its economy. Industries characterized by energy-intensive technology and electricity-generating plants are considered to have significant potential for waste heat recovery and combined heat and power operations. For example, the recent implementation of the district heating system by the Korean government to supply 1.8 million households has already started to improve energy efficiency at the domestic level. However, Korea should explore further opportunities in this sector such as using the recovery of waste heat in district cooling systems to displace electricity usage during summer peaks in the electricity system. Policies for reducing energy use and restraining demand may further enhance energy policy and achieve a higher rate of energy independence, a key factor in Korea's green growth strategy.

Therefore, by allowing non-constant RTS, incorporating ICT capital as an exogenous factor, and including dynamic factor demand aspects, the presented model provided a rich framework for productivity growth and analysis compared with conventional approaches. However, a number of issues may remain unanswered. The approach used in this study is rooted in individual firm optimization that is estimated based on data from industry aggregates. The model assumes that firms in an industry are the same (i.e., they have identical demand curves and the same cost curves). While it is common to study industries from the point of view of a representative firm, it should be noted that the cost function used in this study is assumed to be that of a representative firm in the industry. In this vein, future research could aim to account for the efficiency of using these input factors.

Moreover, the model lends itself to modifications in future research. For example, studies that use more adaptive and flexible functional forms under rational expectations may provide more insights into how ICT capital influences TFP growth. Finally, incorporating important intangible input factors into the model and relaxing the separability assumption between the quasi-fixed factors may also allow us to understand the interaction between these factors and examine more in depth how intangible factors affect TFP growth. 


\section{REFERENCES}

Berndt ER, Fuss MA. Productivity measurement with adjustments for variations in capacity utilization and other forms of temporary equilibrium. Journal of Econometrics 1986;33; 7-29.

Berndt ER, Morrison CJ. Capacity utilization measures: Underlying economic theory and an alternative approach. The American Economic Review 1981;71; 48-52.

Berthélemy JC, Chauvin S. Structural Changes in Asia and Growth Prospects After the Crisis. CEPII, Centre d'Etudes Prospectives et d'Informations Internationales: Paris: France; 2000.

Borensztein A, Lee J-W, 2000. Financial crisis and credit crunch in Korea: Evidence from firm level data (Working Paper No. WP/00/25)

Caves DW, Christensen LR, Diewert WE. Multilateral comparisons of output, input, and productivity using superlative index numbers. The Economic Journal 1982;92; 73-86.

Caves DW, Christensen LR, Swanson JA. Productivity growth, scale economies, and capacity utilization in U.S. railroads, 1955-74. The American Economic Review 1981;71; 994-1002.

Cho Y, Lee J, Kim T-Y. The impact of ICT investment and energy price on industrial electricity demand: Dynamic growth model approach. Energy Policy 2007;35; 4730-4738.

Denny M, Fuss MA, Waverman L, 1981. Substitution Possibilities for Energy: Evidence from US and Canadian Manufacturing Industries, In: E.R. Berndt, Field BC (Eds), Modeling and Measuring Natural Resource Substitution. MIT Press; 1981. pp. 230-288.

Edwards S. Trade orientation, distortions and growth in developing countries. Journal of Development Economics 1992;39; 31-57.

Eichengreen B, Dwight HP, Kwanho S. From Miracle to Maturity: The Growth of the Korean Economy. Harvard University Asia Center; 2012.

Erdmann L, Hilty LM. Exploring the Macroeconomic Impacts of Information and Communication Technologies on Greenhouse Gas Emissions. Journal of Industrial Ecology 2010;14; 826-843.

Ethier WJ. National and international returns to scale in the modern theory of international trade. The American Economic Review 1982;72; 389-405.

Fukao K, Miyagawa T, Pyo HK, 2009. Estimates of multifactor productivity, ICT contributions and resource reallocation effects in Japan and Korea, RIETI Discussion Paper Series 09-E021.

Hall BH, Lotti F, Mairesse J. Evidence on the impact of R\&D and ICT investments on innovation and productivity in Italian firms. Economics of Innovation and New Technology 2012;22; 300-328. 
Hanoch G. The elasticity of scale and the shape of average costs. The American Economic Review 1975;65; 492-497.

Huggett M, Ospina S. Does productivity growth fall after the adoption of new technology? Journal of Monetary Economics 2001;48; 173-195.

Hwang AR. Exports, returns to scale, and total factor productivity: The case of taiwanese manufacturing industries. Review of Development Economics 2003;7; 204-216.

IEA, 2012. Energy policies of IEA countries: The republic of Korea-2012 review. International Energy Association IEA.

Jehle GA, Reny PJ. Advanced Microeconomic Theory, 2nd ed. Addison-Wesley: Pearson Education India; 2001.

Kim M-S, Park Y. The changing pattern of industrial technology linkage structure of Korea: Did the ICT industry play a role in the 1980s and 1990s? Technological Forecasting and Social Change 2009;76; 688-699.

Kim S, Han G. A decomposition of total factor productivity growth in Korean manufacturing industries: A stochastic frontier approach. Journal of Productivity Analysis 2001;16; 269-281.

Kim ST. The role of local public sectors in regional economics growth in Korea. Asian Economic Journal 1997;11; 155-168.

Krueger AO, Tuncer B. Growth of factor productivity in Turkish manufacturing industries. Journal of Development Economics 1982;11; 307-325.

Krugman P. The myth of Asia’s miracle. Foreign Affairs 1994;73; 62-78.

Kwack SY, Sun LY. Economies of scale, technological progress, and the sources of economic growth: case of Korea, 1969-2000. Journal of Policy Modeling 2005;27; 265-283.

Lau LJ, 1986. Functional forms in econometric model building, In: Zvi G, Michael DI (Eds), Handbook of Econometrics, vol. 3. Elsevier; 1986. pp. 1515-1566.

López-Pueyo C, Mancebón M-J. Innovation, accumulation and assimilation: Three sources of productivity growth in ICT industries. Journal of Policy Modeling 2010;32; 268-285.

Maddison A. Monitoring the world economy. Oecd, Paris, Development Center Studies; 2005.

Mokyr, 2005. Long-term economic growth and the history of technology, In: Aghion P, Durlauf S (Eds), Handbook of Economic Growth, vol. 1. Elsevier; 2005. pp. 1113-1180.

Morrison CJ. Productivity measurement with non-static expectations and varying capacity utilization: An integrated approach. Journal of Econometrics 1986;33; 51-74.

Nadiri MI, Prucha IR. A comparison of alternative methods for the estimation of dynamic factor demand models under non-static expectations. Journal of Econometrics 1986;33; 187-211. 
Nadiri MI, Prucha IR. Dynamic factor demand models, productivity measurement, and rates of return: Theory and an empirical application to the US bell system. Structural Change and Economic Dynamics 1990;1; 263-289.

Nadiri MI, Prucha IR. Estimation of the depreciation rate of physical and R\&D capital in the U.S. total manufacturing sector. Economic Inquiry 1996;34; 43-56.

Nadiri MI, Prucha IR. Dynamic factor demand models and productivity analysis. National Bureau of Economic Research Working Paper Series 1999;7079.

Nadiri MI, Prucha IR, 2001. Dynamic Factor Demand Models and Productivity Analysis, In: Hulten CR, Dean ER, Harper MJ (Eds), New Developments in Productivity Analysis. The University of Chicago Press, Chicago and London; 2001. pp. 103-172.

O'Mahony M, Timmer MP. Output, input and productivity measures at the industry level: The EU KLEMS database. The Economic Journal 2009;119; F374-F403.

Oh D, Heshmati A, Lööf H. Technical change and total factor productivity growth for Swedish manufacturing and service industries. Applied Economics 2012;44; 2373-2391.

Oh I, Lee J-D, Heshmati A. Total Factor Productivity in Korean Manufacturing Industries. Global Economic Review 2008;37; 23-50.

Park GM, Park Y. An empirical analysis of the inter-industrial spillover effect of information and communications technology on cost and labor - The case of Korea. Journal of Scientific \& Industrial Research 2003;62; 157-167.

Park PH, 2000. A Reflection on the East Asian Development Model: Comparison of the South Korean and Taiwanese Experiences, In: Richter F-J (Ed), Thailand, Japan, and the East Asian Development Model. Macmillan Press, London; 2000. pp. 141-168.

Park S-R, Kwon JK. Rapid economic growth with increasing returns to scale and little or no productivity growth. The Review of Economics and Statistics 1995;77; 332-351.

Pilat D, Lee FC, 2001. Productivity Growth in ICTproducing and ICT-using Industries: A Source of Growth Differentials in the OECD?, in: OECD Science TaI (Ed.), Working Papers 2001/04. OECD Publishing.

Polder M, Van Leeuwen G, Mohnen P, Raymond W, 2009. Productivity effects of innovation modes. Statistics Netherlands Discussion Paper no 09033. Statistics Netherlands Discussion Paper no 09033, Netherlands.

Pyo HK, Rhee KH, Ha BC, 2007. Growth accounting and productivity analysis by 33 industrial sectors in Korea (1984-2002), In: Jorgenson DW, Kuroda M, Motohashi K (Eds), Productivity in Asia: Economics growth and compitetiviness. MPG Books Ltd, U.K: Bodmin, Cornwall; 2007. 
Røpke I, Christensen TH. Energy impacts of ICT - Insights from an everyday life perspective. Telematics and Informatics 2012;29; 348-361.

Schumpeter J. Business Cycles: A Theoretical, Historical, and Statistical Analysis of the Capitalist Process. McGraw-Hill: New York; 1939.

Solow RM. Technical change and the aggregate production function. The Review of Economics and Statistics 1957;39; 312-320.

Tangen S, 2002. "Understanding the concept of productivity, Proceedings of the 7th

Asia-Pacific Industrial Engineering and Management Systems Conference, Taipei, pp. 18-20.

Toro EF. Riemann solvers and numerical methods for fluid dynamics: A practical introduction. Springer: Verlag Berlin Heidelberg; 2009.

van Ark B, Inklaar R, McGuckin RH. ICT and Productivity in Europe and the United States Where Do the Differences Come From? CESifo Economic Studies 2003;49; 295-318. 


\section{Appendix A}

Estimated System of Factor Demand Equations

The following dynamic cost function is solved with respect to the quasi-fixed factors with static expectation:

(A.1) $\min _{K_{t+\tau}, I C T_{t+\tau}} \sum_{\tau=1}^{\infty}\left[G\left(p_{i, t}^{L}, p_{i, t}^{E}, K_{i, t+\tau-1}, I C T_{i, t+\tau-1}, \Delta K_{i, t+\tau}, \Delta I C T_{i, t+\tau}, h\left(Y_{i, t+\tau}\right), T_{i, t+\tau}\right)+\right.$ $\left.p_{i, t}^{K} I_{i, t+\tau,}+p_{i, t}^{I C T} H_{i, t+\tau}\right]\left(1+r_{i, t}\right)^{-\tau}$

Subjects to:

$I_{i, t+\tau}=K_{i, t+\tau}-(1-\delta) K_{i, t+\tau-1}$

$H_{i, t+\tau}=I C T_{i, t+\tau}-(1-\mu) I C T_{i, t+\tau-1}$

where $p^{E}, p^{L}, p^{I C T}$, and $p^{K}$ are prices for energy, labor, ICT capital, and non-ICT capital normalized by the price of materials, respectively. $H$ and $I$ are the real investment in ICT capital and non-ICT capital, respectively. The depreciation rates of ICT and non-ICT capital are $\mu$ and $\delta$, respectively, and $r$ denotes the discount rate.

The normalized restricted cost function $G($.$) in a quadratic form, as introduced by Denny et al.$ (1981), can be described as follows:

(A.2) $G\left(p_{i, t}^{L}, p_{i, t}^{E}, K_{i, t-1}, I C T_{i, t-1}, \Delta K_{i, t}, \Delta I C T_{i, t}, h\left(Y_{i, t}\right), T_{i, t}\right)=\left[a_{0}+a_{T} T_{i, t}+a_{l} p_{i, t}^{L}+a_{e} p_{i, t}^{E}+\right.$ $\left.a_{e l} p_{i, t}^{L} p_{i, t}^{E}+\frac{1}{2} a_{l l}\left(p_{i, t}^{L}\right)^{2}+\frac{1}{2} a_{e e}\left(p_{i, t}^{E}\right)^{2}\right] h\left(Y_{i, t}\right)+a_{K} K_{i, t-1}+a_{I C T} I C T_{i, t-1}+a_{l K} p_{i, t}^{L} K_{i, t-1}+$ $a_{l I C T} p_{i, t}^{L} I C T_{i, t-1}+a_{e K} p_{i, t}^{E} K_{i, t-1}+a_{e I C T} p_{i, t}^{E} I C T_{i, t-1}+\left[\frac{1}{2} a_{K K} \mathrm{~K}_{i, t-1}^{2}+\frac{1}{2} a_{I C T I C T} \mathrm{ICT}_{i, t-1}^{2}+\right.$ $\left.\frac{1}{2} a_{\dot{K} \dot{K}} \Delta \mathrm{K}_{i, t}^{2}+\frac{1}{2} a_{I \dot{C} T I \dot{C} T} \Delta \mathrm{ICT}_{i, t}^{2}\right] \frac{1}{h\left(Y_{i, t}\right)}$

The normalized restricted cost function specified in equation (A.2), corresponding to a homothetic production function, its general form is as follows:

$$
\mathrm{g}\left(p_{i, t}^{L}, p_{i, t}^{E}, \frac{K_{i, t-1}}{H(Y)}, \frac{I C T_{i, t-1}}{H(Y)}, \frac{\Delta K_{i, t}}{H(Y)}, \frac{\Delta I C T_{i, t}}{H(Y)}, T_{i, t}\right) H(Y)
$$

where $H(Y)$ is a function of $Y$. The elasticity scale can then be obtained as $H(Y) / Y(d Y / d H)$. For a homothetic production function, the scale elasticity is a function of output alone and is independent of any specific direction of a change in inputs (Hanoch, 1975). RTS can be measured as an inverse of scale elasticity (Nadiri and Prucha, 1999). The marginal adjustment cost needs to be equal to zero at the steady state of the quasi-fixed inputs when $\triangle K$ and $\triangle I C T$ are equal to zero. Hence, $\partial G(.) / \partial \Delta K$ and $\partial G(.) / \partial \Delta I C T$ will be zero at $\Delta K=\Delta I C T=0$ only if the following restrictions are imposed on the estimated parameters (Denny et al., 1981):

$$
a_{\dot{K}}=a_{I \dot{C} T}=a_{l \dot{K}}=a_{I I \dot{C} T}=a_{K \dot{K}}=a_{I C T I \dot{C} T}=a_{\dot{K} I \dot{C} T}=a_{I C T \dot{K}}=a_{T \dot{K}}=a_{T I \dot{C} T}=0
$$


where a dot over a variable represents the growth rate of the quasi-fixed inputs. Imposing the separability assumption on the quasi-fixed inputs will simplify the derivation of the dynamic factor demand model. In this study, the separability of the quasi-fixed input implies that $\mathrm{a}_{\mathrm{KICT}}=$ $\mathrm{a}_{\mathrm{K} \mathbf{I} I \mathrm{C}}$. The convexity and concavity conditions of the normalized restricted cost function under the separability assumption imply that $\mathrm{a}_{\mathrm{KK}}, \mathrm{a}_{\text {ICTICT }}, \mathrm{a}_{\dot{\mathrm{K} \dot{K}}}, \mathrm{a}_{\text {IĆTIC்T }}>0$, and $\mathrm{a}_{11}, \mathrm{a}_{\mathrm{ee}}<0$.

The optimal input paths of investment in ICT and non-ICT capital must satisfy the necessary conditions given by the Euler equations (Toro, 2009), obtained by solving equation (A.1) with respect to $K$ and $I C T$ as follows:

$$
\begin{aligned}
& \text { (A.5) }-a_{\dot{K} \dot{K}} K_{i, t+\tau+1}+\left[a_{\dot{K} \dot{K}}+\left(2+r_{i, t}\right) a_{\dot{K} \dot{K}}\right] K_{i, t+\tau}-\left(1+r_{i, t}\right) a_{\dot{K} \dot{K}} K_{i, t+\tau-1}=-((1- \\
& \left.\delta) p_{i, t}^{K}+a_{K}+a_{l K} p_{i, t}^{L}+a_{e K} p_{i, t}^{E}+a_{T K} T_{i, t}\right) h\left(Y_{i, t}\right)
\end{aligned}
$$

$$
\begin{gathered}
-a_{I \dot{C} T I \dot{C} T} I C T_{i, t+\tau+1}+\left[a_{I \dot{C} T I \dot{C} T}+\left(2+r_{i, t}\right) a_{I \dot{C} T I \dot{C} T}\right] I C T_{i, t+\tau}- \\
\left(1+r_{i, t}\right) a_{I \dot{C} T I \dot{C} T} I C T_{i, t+\tau-1}=-\left((1-\mu) p_{i, t}^{I C T}+a_{I C T}+a_{l I C T} p_{i, t}^{L}+a_{e I C T} p_{i, t}^{E}+a_{T I C T} T_{i, t}\right) h\left(Y_{i, t}\right)
\end{gathered}
$$

The transversality conditions below will rule out the unstable roots for the Euler equations:

$\lim _{n \rightarrow \infty}\left(1+r_{i, \tau}\right)^{\tau}\left(a_{\dot{K} \dot{K}} K_{i, t+\tau}-a_{\dot{K} \dot{K}} K_{i, t+\tau-1}\right)=0$, and

$\lim _{n \rightarrow \infty}\left(1+r_{i, \tau}\right)^{\tau}\left(a_{I \dot{C} T I \dot{C} T} \mathrm{ICT}_{i, t+\tau}-a_{\text {I } \dot{C} T \dot{C} T} \mathrm{ICT}_{i, t+\tau-1}\right)=0$,

The accelerator equations serve as a solution that corresponds to the stable roots for the Euler equations as follows:

$$
\begin{array}{ll}
\text { (A.7.1) } & \Delta K_{i, t}=m_{K K}\left(K_{i, t}^{*}-K_{i, t-1}\right) \\
\text { (A.7.2) } & \Delta I C T_{i, t}=m_{\text {ICTICT }}\left(I C T_{i, t}^{*}-I C T_{i, t-1}\right) \\
\text { (A.7.3) } & m_{K K}=-\frac{1}{2}\left[\left(r_{i, t}+a_{K K} / a_{\dot{K} \dot{K}}\right)-\left(\left(r_{i, t}\right.\right.\right. \\
\text { (A.7.4) } & m_{\text {ICTICT }}=-\frac{1}{2}\left[\left(r_{i, t}+a_{\text {ICTICT }} / a_{\text {IC } \dot{C} \text { I } \dot{C} T}\right)\right. \\
\left.\left.4 a_{\text {ICTICT }} / a_{\text {İंTICT }}\right)^{1 / 2}\right]
\end{array}
$$

$$
\begin{aligned}
& K_{i, t}^{*}=-\frac{1}{a_{K K}}\left[\left(r_{i, t}+\delta\right) p_{i, t}^{K}+a_{K}+a_{l K} p_{i, t}^{L}+a_{e K} p_{i, t}^{E}+a_{T K} T_{i, t}\right] h\left(Y_{i, t}\right) \\
& I C T_{i, t}^{*}=-\frac{1}{a_{\text {ICTICT }}}\left[\left(r_{i, t}+\mu\right) p_{i, t}^{I C T}+a_{I C T}+a_{l I C T} p_{i, t}^{L}+a_{e I C T} p_{i, t}^{E}+a_{T I C T} T_{i, t}\right] h\left(Y_{i, t}\right)
\end{aligned}
$$

where a star indicates the optimal or target levels of the quasi-fixed inputs.

Substituting the steady-state solutions of the Euler equations (A.5) and (A.6) and the adjustment coefficient forms (A.7.1) and (A.7.2) into the accelerator coefficients (A.7.3) and (A.7.4), 
respectively, in line with Nadiri and Prucha (1990), this will provide the optimal quasi-fixed input path for ICT and non-ICT capital as follows:

(A.8) $\Delta K_{i, t}=\left(-\frac{1}{2}\left[\left(r_{i, t}+a_{K K} / a_{\dot{K} \dot{K}}\right)-\left(\left(r_{i, t}+a_{K K} / a_{\dot{K} \dot{K}}\right)^{2}+4 a_{K K} / a_{\dot{K} \dot{K}}\right)^{1 / 2}\right]\right) *$
$\left(-\frac{1}{a_{K K}}\left[\left(r_{i, t}+\delta\right) p_{i, t}^{K}+a_{K}+a_{l K} p_{i, t}^{L}+a_{e K} p_{i, t}^{E}+a_{T K} T_{i, t}\right] h\left(Y_{i, t}\right)-K_{i, t-1}\right)$

$\triangle I C T_{i, t}=$

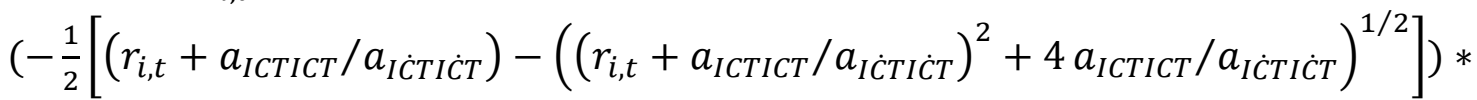

$\left(-\frac{1}{a_{\text {ICTICT }}}\left[\left(r_{i, t}+\mu\right) p_{i, t}^{I C T}+a_{I C T}+a_{l I C T} p_{i, t}^{L}+a_{e I C T} p_{i, t}^{E}+a_{T I C T} T_{i, t}\right] h\left(Y_{i, t}\right)-I C T_{i, t-1}\right)$

From Shephard's lemma, the variable input demand equations for labor $L$, energy use $E$, and materials $M$ can be obtained from the variable cost function as follows:

(A.10) $L_{i, t}=\frac{\partial G(.)}{\partial p_{i, t}^{L}}=\left(a_{l}+a_{l l} p_{i, t}^{L}+a_{e l} p_{i, t}^{E}\right) h\left(Y_{i, t}\right)+a_{l K} K_{i, t-1}+a_{l I C T} I C T_{i, t-1}$

(A.11) $E_{i, t}=\frac{\partial G(.)}{\partial p_{i, t}^{E}}=\left(a_{e}+a_{e e} p_{i, t}^{E}+a_{e l} p_{i, t}^{L}\right) h\left(Y_{i, t}\right)+a_{e K} K_{i, t-1}+a_{e I C T} I C T_{i, t-1}$

From $G()=.M_{i, t}+p_{i, t}^{L} L_{i, t}+p_{i, t}^{E} E_{i, t}$, the demand equation for $M$ is described as follows:

(A.12) $M_{i, t}=G()-.p_{i, t}^{L} L_{i, t}-p_{i, t}^{E} E_{i, t}=\left[a_{0}+a_{T} T_{i, t}-\frac{1}{2} a_{l l}\left(p_{i, t}^{L}\right)^{2}-\frac{1}{2} a_{e e}\left(p_{i, t}^{E}\right)^{2}-\right.$

$\left.a_{e l} p_{i, t}^{L} p_{i, t}^{E}\right] h\left(Y_{i, t}\right)+a_{K} K_{i, t-1}+a_{I C T} I C T_{i, t-1}+\left[\frac{1}{2} a_{K K} \mathrm{~K}_{i, t-1}^{2}+\frac{1}{2} a_{I C T I C T} \mathrm{ICT}_{i, t-1}^{2}+\frac{1}{2} a_{\dot{K} \dot{K}} \Delta \mathrm{K}_{i, t}^{2}+\right.$ $\left.\frac{1}{2} a_{I \dot{C} T I \dot{C} T} \Delta \mathrm{ICT}_{i, t}^{2}\right] \frac{1}{h\left(Y_{i, t}\right)}$

The entire system of equations to be estimated consists of the two quasi-fixed inputs ( $K$ and $I C T)$ and three variable inputs ( $L, E$, and $M$ ) presented in equations (A.8)-(A.12). The industry dummy variables and a stochastic error term is added to each equation in order to capture the industry fixed effects and random errors in cost minimization problem, respectively. The system of equations is non-linear in both parameters and variables; therefore, it needs to be estimated by using non-linear estimation methods. We thus estimate the model parameters by using the fullinformation maximum likelihood (FIML) method with the SAS 9.3 application package. 


\section{Appendix B}

The Decomposition of TFP

According to the lemma presented by Nadiri and Prucha (1990), the relationship between the derivatives of the production function $F(V, X, \Delta X, T)$ and those of the restricted cost function $G\left(p^{V}, X, \Delta X, Y, T\right)=V_{1}+p^{v 2} V_{2}+p^{v 3} V_{3}$ can be expressed as follows:

$$
\begin{aligned}
& \frac{\partial F}{\partial V_{1}}=\frac{1}{\partial G / \partial Y}, \quad \frac{\partial F}{\partial V_{2}}=\frac{p^{V_{2}}}{\partial G / \partial Y}, \quad \frac{\partial F}{\partial V_{3}}=\frac{p^{V_{3}}}{\partial G / \partial Y}, \\
& \frac{\partial F}{\partial X_{1, t-1}}=-\frac{\partial G / \partial X_{1, t-1}}{\partial G / \partial Y}, \quad \frac{\partial F}{\partial X_{2, t-1}}=-\frac{\partial G / \partial X_{2, t-1}}{\partial G / \partial Y}, \\
& \frac{\partial F}{\partial \Delta X_{1, t-1}}=-\frac{\partial G / \partial \Delta X_{1, t-1}}{\partial G / \partial Y}, \quad \frac{\partial F}{\partial \Delta X_{2, t-1}}=-\frac{\partial G / \partial \Delta X_{2, t-1}}{\partial G / \partial Y}, \\
& \frac{\partial F}{\partial T}=-\frac{\partial G / \partial T}{\partial G / \partial Y}
\end{aligned}
$$

where, $\mathrm{v}_{1}, \mathrm{v}_{2}$, and $\mathrm{v}_{3}$ are the variable inputs materials, labor, and energy, respectively, with their respective price $1, p^{v 2}$, and $p^{v 3}$. $X_{1}$ and $X_{2}$ denote the quasi-fixed inputs.

By differentiating the production function $F(V, X, \Delta X, T)$ with respect to time and dividing by output, we can decompose output growth:

$$
\begin{aligned}
& \text { (B.1) } \Delta \operatorname{lnh}\left(Y_{i, t}\right)=\frac{1}{2}\left[\left(\epsilon_{F L}(t)+\epsilon_{F L}(t-1) \Delta \ln L_{i, t}\right)+\left(\epsilon_{F E}(t)+\epsilon_{F E}(t-1) \Delta \ln E_{i, t}\right)+\right. \\
& \left(\epsilon_{F M}(t)+\epsilon_{F M}(t-1) \Delta \ln M_{i, t}\right)+\left(\epsilon_{F K_{t-1}}(t)+\epsilon_{F K_{t-1}}(t-1) \Delta \ln K_{i, t-1}\right)+\left(\epsilon_{F I C T_{t-1}}(t)+\right. \\
& \left.\epsilon_{F I C T_{t-1}}(t-1) \Delta \ln I C T_{i, t-1}\right)+\left(\epsilon_{F \Delta K}(t)+\epsilon_{F \Delta K}(t-1) \Delta \ln \Delta K_{i, t}\right)+\left(\epsilon_{F \Delta I C T}(t)+\epsilon_{F \Delta I C T}(t-\right. \\
& \text { 1) } \left.\left.\Delta \ln \Delta I C T_{i, t}\right)\right]+\frac{1}{2}\left[\lambda_{Y}(t)+\lambda_{Y}(t-1)\right] \ldots(26)
\end{aligned}
$$

Where, $\epsilon_{F J}\left(J=L, E, M, K_{t-1}, I C T_{t-1}, \Delta K_{t}, \Delta I C T_{t}\right)$ are the elasticities of output with respect to the inputs. The shadow price of $X_{t-1}$ and $\Delta X_{t}$ and shadow cost $C^{S}$ are defined as follows:

$$
C^{S}=G+\sum_{j=1}^{2} u_{j} X_{j, t-1}+\sum_{j=1}^{2} \dot{u}_{J} \Delta X_{j t}, \text { where } u_{j}=-\frac{\partial G}{\partial X_{j, t-1}} \text { and } \dot{u}_{\jmath}=-\frac{\partial G}{\partial \Delta X_{j}}
$$

Total cost $C$, shadow cost $C^{S}$, and RTS $\varepsilon$ imply that $C^{S}=\varepsilon(\partial G / \partial H) H$. Where $\mathrm{H}$ is a function in Y. From the relationship between the derivatives of the production function and those of the restricted cost function and from the decomposition of output growth, we thus obtain the following relations:

$$
C_{i, \tau}^{S}+\lambda_{Y}(t)
$$


(B.4) $\Delta \ln H_{i, t}=\frac{1}{2}\left(\Delta \ln H_{i, t}^{t}+\Delta \ln H_{i, t}^{t-1}\right)$ where $\tau=\mathrm{t}$, t-1

The growth rate of the cost-weighted index of aggregate inputs can be expressed as follows:

(B.5) $\Delta \ln N_{i, t}^{\tau}=\left[p_{i, \tau}^{L} L_{i, \tau} \Delta \ln L_{i, t}+p_{i, \tau}^{E} E_{i, \tau} \Delta \ln E_{i, t}+p_{i, \tau}^{M} M_{i, \tau} \Delta \ln M_{i, t}+q_{i, \tau}^{K} K_{i, \tau-1} \Delta \ln K_{i, t-1}+\right.$

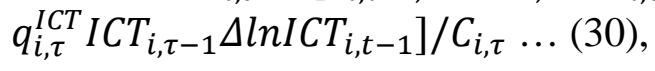

$\Delta \ln N_{i, t}=\Delta \ln N_{i, t}^{t}+\Delta \ln N_{i, t}^{t-1}$ where $\tau=\mathrm{t}, \mathrm{t}-1$ 


\section{Appendix C}

Data Sources and Construction of the Variables

The data used in this study are obtained from secondary data sources, mainly the harmonized Asia KLEMS growth and productivity accounts database (June 2012 release). The input measures include various categories of capital, labor, energy use, materials, ICT capital, and services inputs. Total hours worked is used for labor input. The materials and energy use inputs are computed from the proportion of each of these inputs from the national accounts. Energy use is defined as the aggregate of energy mining, oil refining, and electricity and gas products ${ }^{8}$. Real non-ICT capital stock (converted into 2005 prices) is taken from the Korea Industrial Productivity 2012 database $^{9}$. The macroeconomic variables are taken from the Bank of Korea's Economic Statistics System.

In addition to the measures mentioned above, the variables in this study are export/importoriented industry, industry size, R\&D intensity, and labor skills for the 30 sampled sectors (see table C.2). The rental rate of capital stock is defined as $p^{K}=p_{K}(\delta+r)(1-\tau)$, where $p_{\mathrm{k}}$ is the chained Fisher price index of capital stock, $\delta$ is the physical capital deflator, $r$ is the real discount rate, and $\tau$ is the corporate tax rate (assumed to be 30 percent). Table C. 1 presents the definition of the variables used:

Table C.1

Definition of variables used

\begin{tabular}{|c|c|c|}
\hline Variable & Formula & Source \\
\hline \multicolumn{3}{|c|}{ Industry Code } \\
\hline \multicolumn{3}{|l|}{ Year } \\
\hline IFPV & $\begin{array}{l}\text { Price Index of Gross Output (Index, } \\
2005=100 \text { for Korea }\end{array}$ & $\begin{array}{l}\text { Asia KLEMS Growth And Productivity Database } \\
\text { for Korea }\end{array}$ \\
\hline IFPK & Price Index of Capital Stock & $=$ \\
\hline IFPICT & Price Index of ICT Capital Stock & $=$ \\
\hline IFPL & Price Index of Labor & $=$ \\
\hline IFPE & Price Index of Energy & $=$ \\
\hline IFPM & Price Index of Materials & $=$ \\
\hline PVV & $\begin{array}{l}\text { PVV = Gross Output In Current } \\
\text { Prices }\end{array}$ & $=$ \\
\hline PKK & $\begin{array}{l}\text { Real Non ICT Capital Stock (In } \\
2005 \text { Prices for Korea }\end{array}$ & $\begin{array}{l}\text { The Real Capital Stock is taken form the KIP } \\
\text { Database for Korea. The physical share of non- } \\
\text { ICT Capital is calculated after subtracting the real } \\
\text { share of ICT Capital. }\end{array}$ \\
\hline PICT & Real ICT Capital Stock & $\begin{array}{l}\text { The share is taken from the KLEMS database, } \\
\text { multiplied by the Real Capital Stock }\end{array}$ \\
\hline PLL & $\begin{array}{l}\text { Total Hours Worked By Employees } \\
\text { (Millions) }\end{array}$ & $=$ \\
\hline PEE & Cost of Energy Input (Million KW) & $=$ \\
\hline
\end{tabular}

\footnotetext{
${ }^{8}$ For details about the KLEMS growth accounting database, see O'Mahony M, Timmer MP. Output, input and productivity measures at the industry level: The EU KLEMS database. The Economic Journal 2009;119; F374-F403. ${ }^{9}$ These data are publically available at: http://www.kpc.or.kr/eng/state/2012_kip.asp?c_menu=5\&s_menu=5_4 4
} 


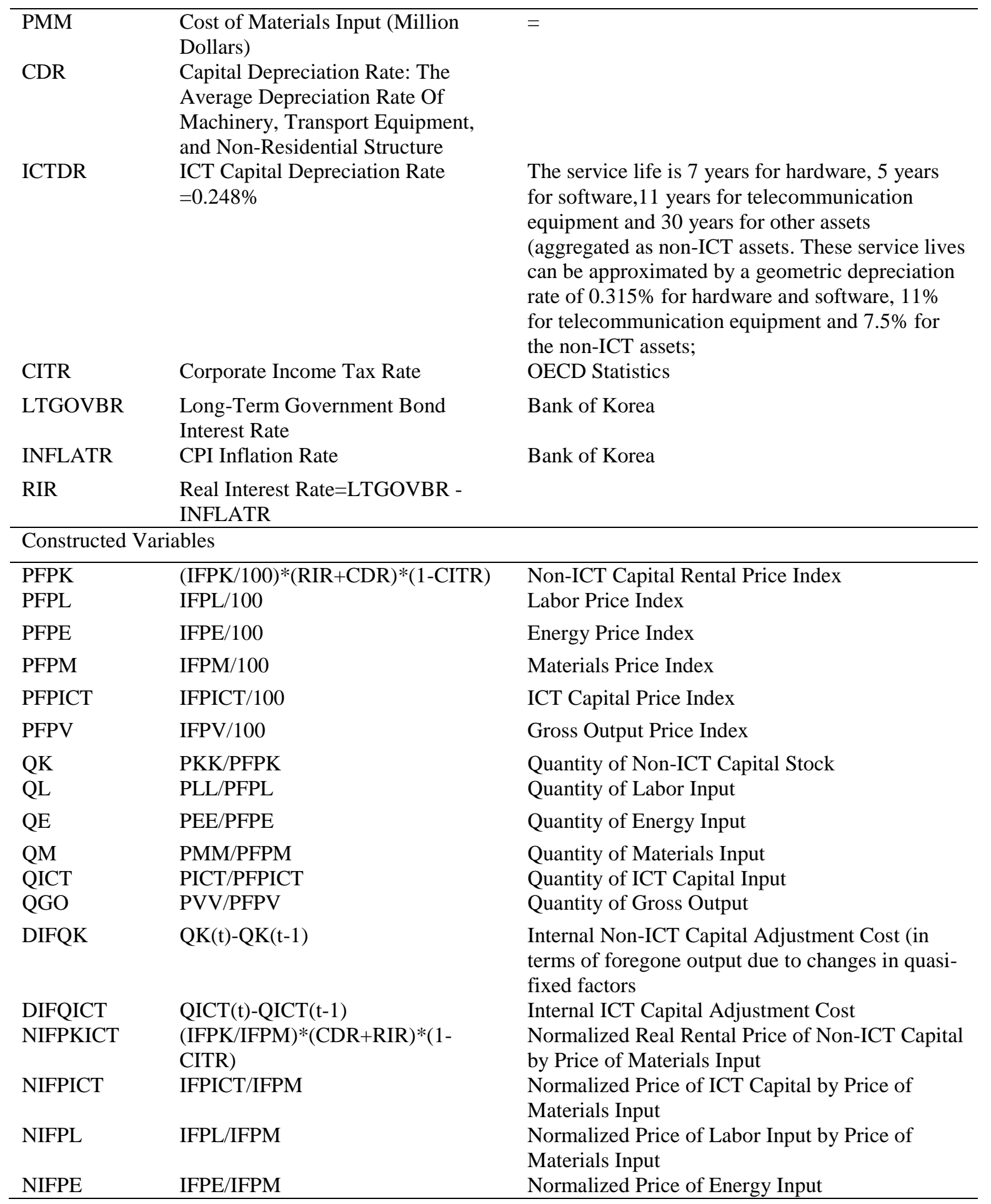


Table C. 2

Industry Sectors Classification ${ }^{*}$

\begin{tabular}{|c|c|c|c|c|}
\hline ID & Description & $\begin{array}{l}\text { Technology } \\
\text { Level }\end{array}$ & $\begin{array}{l}\text { Export } \\
\text { Market } \\
\text { Orientation }\end{array}$ & $\begin{array}{l}\mathrm{R} \& \mathrm{D} \\
\text { Intensity }\end{array}$ \\
\hline 1 & $\begin{array}{l}\text { Agriculture, Hunting, } \\
\text { Forestry and Fishing }\end{array}$ & $\mathrm{L}$ & $\mathrm{L}$ & M \\
\hline 2 & Mining and Quarrying & $\mathrm{L}$ & $\mathrm{L}$ & $\mathrm{L}$ \\
\hline 3 & $\begin{array}{l}\text { Food, Beverages and } \\
\text { Tobacco }\end{array}$ & $\mathrm{L}$ & $\mathrm{M}$ & M \\
\hline 4 & $\begin{array}{l}\text { Textiles, Leather and } \\
\text { Footwear }\end{array}$ & $\mathrm{L}$ & I & M \\
\hline 5 & Wood and Cork & $\mathrm{L}$ & $\mathrm{L}$ & $\mathrm{L}$ \\
\hline 6 & $\begin{array}{l}\text { Pulp, Paper, Printing and } \\
\text { Publishing }\end{array}$ & $\mathrm{L}$ & M & $\mathrm{H}$ \\
\hline 7 & $\begin{array}{l}\text { Coke, Refined Petroleum } \\
\text { and Nuclear Fuel }\end{array}$ & $\mathrm{H}$ & $\mathrm{L}$ & $\mathrm{H}$ \\
\hline 8 & $\begin{array}{l}\text { Chemicals and Chemical } \\
\text { Products }\end{array}$ & $\mathrm{H}$ & I & M \\
\hline 9 & Rubber and Plastics & $\mathrm{H}$ & I & $\mathrm{M}$ \\
\hline 10 & Other Non-Metallic Mineral & M & M & M \\
\hline 11 & $\begin{array}{l}\text { Basic Metals and Fabricated } \\
\text { Metal }\end{array}$ & $\mathrm{M}$ & $\mathrm{M}$ & $\mathrm{L}$ \\
\hline 12 & Machinery, NEC & $\mathrm{H}$ & I & $\mathrm{H}$ \\
\hline 13 & $\begin{array}{l}\text { Electrical and Optical } \\
\text { Equipment }\end{array}$ & $\mathrm{H}$ & I & $\mathrm{H}$ \\
\hline 14 & Transport Equipment & $\mathrm{H}$ & $\mathrm{I}$ & M \\
\hline 15 & $\begin{array}{l}\text { Manufacturing NEC; } \\
\text { Recycling }\end{array}$ & $\mathrm{H}$ & I & M \\
\hline 16 & $\begin{array}{l}\text { Electricity, Gas and Water } \\
\text { Supply }\end{array}$ & M & $\mathrm{L}$ & $\mathrm{H}$ \\
\hline 17 & $\begin{array}{l}\text { Construction } \\
\text { Sale, Maintenance and }\end{array}$ & $\mathrm{H}$ & I & $\mathrm{H}$ \\
\hline 18 & $\begin{array}{l}\text { Repair of Motor Vehicles } \\
\text { and Motorcycles; Retail Sale } \\
\text { of Fuel }\end{array}$ & $\mathrm{L}$ & $\mathrm{L}$ & $\mathrm{L}$ \\
\hline 19 & $\begin{array}{l}\text { Wholesale Trade and } \\
\text { Commission Trade, Except } \\
\text { of Motor Vehicles and } \\
\text { Motorcycles }\end{array}$ & $\mathrm{L}$ & $\mathrm{L}$ & $\mathrm{L}$ \\
\hline 20 & $\begin{array}{l}\text { Retail Trade, Except of } \\
\text { Motor Vehicles and } \\
\text { Motorcycles; Repair of } \\
\text { Household Goods }\end{array}$ & $\mathrm{L}$ & $\mathrm{L}$ & L \\
\hline 21 & Hotels and Restaurants & $\mathrm{L}$ & $\mathrm{L}$ & $\mathrm{L}$ \\
\hline 22 & Transport and Storage & $\mathrm{M}$ & $\mathrm{L}$ & $\mathrm{L}$ \\
\hline 23 & $\begin{array}{l}\text { Post and } \\
\text { Telecommunications }\end{array}$ & $\mathrm{H}$ & I & $\mathrm{H}$ \\
\hline 24 & Financial Intermediation & M & $\mathrm{L}$ & $\mathrm{H}$ \\
\hline 25 & Real Estate Activities & $\mathrm{L}$ & $\mathrm{L}$ & $\mathrm{L}$ \\
\hline 26 & $\begin{array}{l}\text { Renting of M\&Eq and Other } \\
\text { Business Activities }\end{array}$ & $\mathrm{L}$ & $\mathrm{L}$ & L \\
\hline 27 & Public Admin and Defense; & $\mathrm{L}$ & $\mathrm{L}$ & $\mathrm{L}$ \\
\hline
\end{tabular}




\begin{tabular}{|c|c|c|c|c|}
\hline & Compulsory Social Security & & & \\
\hline 28 & Education & $\mathrm{L}$ & $\mathrm{L}$ & $\mathrm{H}$ \\
\hline 29 & Health and Social Work & $\mathrm{H}$ & $\mathrm{L}$ & $\mathrm{L}$ \\
\hline 30 & $\begin{array}{l}\text { Other Community, Social } \\
\text { And Personal Services }\end{array}$ & $\mathrm{L}$ & $\mathrm{L}$ & $\mathrm{L}$ \\
\hline
\end{tabular}

*The letters H, M, and L refer to High, Medium, and Low, respectively. 
Table C.3

FIML Parameter Estimates for Dynamic Factor Demand Model

\begin{tabular}{|c|c|c|c|c|c|}
\hline Parameter & Estimate & t Value & Parameter & Estimate & t Value \\
\hline$a_{k k}$ & $\begin{array}{l}0.097 * * * \\
(0.005)\end{array}$ & 17.8 & $\mathrm{a}_{\mathrm{l}}$ & $\begin{array}{l}0.991 * * * \\
(0.055)\end{array}$ & 18.08 \\
\hline $\mathrm{a}_{\text {koko }}$ & $\begin{array}{l}1.952^{* * *} \\
(0.12)\end{array}$ & 16.26 & $\mathrm{a}_{11}$ & $\begin{array}{l}-0.014^{* *} \\
(0.006)\end{array}$ & -2.1 \\
\hline$a_{k}$ & $\begin{array}{l}-0.157 * * * \\
(0.007)\end{array}$ & -22.15 & $\mathrm{a}_{\mathrm{el}}$ & $\begin{array}{l}0.014^{* * *} \\
(0.004)\end{array}$ & 3.99 \\
\hline $\mathrm{a}_{\mathrm{lk}}$ & $\begin{array}{l}-0.045 * * * \\
(0.004)\end{array}$ & -12.74 & $\mathrm{a}_{\mathrm{e}}$ & $\begin{array}{l}0.851^{* * *} \\
(0.029)\end{array}$ & 29.47 \\
\hline$a_{e k}$ & $\begin{array}{l}-0.036 * * * \\
(0.003)\end{array}$ & -12.98 & $\mathrm{a}_{\mathrm{ee}}$ & $\begin{array}{l}-0.007 * * * \\
(0.002)\end{array}$ & -3.53 \\
\hline $\mathrm{a}_{\mathrm{ii}}$ & $\begin{array}{l}0.124 * * * \\
(0.004)\end{array}$ & 32.41 & $\mathrm{a}_{0}$ & $\begin{array}{l}0.948 * * * \\
(0.033)\end{array}$ & 28.36 \\
\hline$a_{\text {ioio }}$ & $\begin{array}{l}1.334^{* * * *} \\
(0.053)\end{array}$ & 25.23 & $\mathrm{a}_{\mathrm{t}}$ & $\begin{array}{l}-0.002^{* * *} \\
(0.001)\end{array}$ & 3.12 \\
\hline$a_{i}$ & $\begin{array}{l}-0.235 * * * \\
(0.007)\end{array}$ & -33.69 & $\Omega_{0}$ & $\begin{array}{l}0.663 * * * \\
(0.012)\end{array}$ & 55.38 \\
\hline $\mathrm{a}_{\mathrm{li}}$ & $\begin{array}{l}-0.076 * * * \\
(0.007)\end{array}$ & -11.37 & $\Omega_{1}$ & $\begin{array}{l}0.011^{*} \\
(0.008)\end{array}$ & 1.37 \\
\hline $\mathrm{a}_{\mathrm{ei}}$ & $\begin{array}{l}-0.060 * * * \\
(0.004)\end{array}$ & -13.63 & \multicolumn{3}{|c|}{ Log Likelihood: 631.699} \\
\hline
\end{tabular}

Note: standard deviations are between parentheses. 
Table C.4

Short- and Long-run Price and Output Elasticities in the South Korean Industries (1995)*

\begin{tabular}{lrrlrr}
\hline Elasticitities & Short Run & Long Run & Elasticitities & Short Run & \multicolumn{1}{c}{ Long Run } \\
\hline$\varepsilon_{\text {Lpl }}$ & -0.12 & -0.052 & $\varepsilon_{\mathrm{Kpk}}$ & 0 & -0.3182 \\
\hline$\varepsilon_{\text {Lpe }}$ & 0.069 & 0.123 & $\varepsilon_{\mathrm{KpICT}}$ & 0 & 0 \\
\hline$\varepsilon_{\mathrm{Lpm}}$ & 0.051 & 0.189 & $\varepsilon_{\mathrm{ICTpl}}$ & 0 & 1.334 \\
\hline$\varepsilon_{\mathrm{Epl}}$ & 0.014 & 0.068 & $\varepsilon_{\mathrm{ICTpe}}$ & 0 & 0.812 \\
\hline$\varepsilon_{\mathrm{Epe}}$ & -0.006 & -0.037 & $\varepsilon_{\mathrm{ICTpm}}$ & 0 & -0.818 \\
\hline$\varepsilon_{\mathrm{Epm}}$ & -0.008 & 0.101 & $\varepsilon_{\mathrm{ICTpk}}$ & 0 & 0 \\
\hline$\varepsilon_{\mathrm{Mpl}}$ & 0.011 & -0.288 & $\varepsilon_{\mathrm{ICTpICT}}$ & 0 & -1.328 \\
\hline$\varepsilon_{\mathrm{Mpe}}$ & -0.008 & -0.244 & $\varepsilon_{\mathrm{KY}}$ & 0.070 & 0.076 \\
\hline$\varepsilon_{\mathrm{Mpm}}$ & -0.003 & -0.605 & $\varepsilon_{\mathrm{ICTY}}$ & 0.081 & 0.086 \\
\hline$\varepsilon_{\mathrm{Kpl}}$ & 0 & 0.554 & $\varepsilon_{\mathrm{LY}}$ & 0.37 & 0.37 \\
\hline$\varepsilon \mathrm{Kpe}$ & 0 & 0.352 & $\varepsilon_{\mathrm{EY}}$ & 0.06 & 0.07 \\
\hline$\varepsilon_{\mathrm{Kpm}}$ & 0 & -0.588 & $\varepsilon_{\mathrm{MY}}$ & 0.08 & 0.06 \\
\hline
\end{tabular}

* $\varepsilon_{\mathrm{Z}}$ (Z=L,M,E,K,ICT) denotes the elasticity of factor $\mathrm{Z}$ with respect to $\mathrm{pl}$ (wage rate), pe(price of energy), pm (price of materials), pICT (rental price of ICT capital), and pk(rental price of non-ICT capital) 